\title{
Algal Proteins: Extraction, Application, and Challenges Concerning Production
}

\author{
Stephen Bleakley ${ }^{1,2}$ and Maria Hayes ${ }^{1, *}$ \\ 1 Food Biosciences Department, Teagasc Ashtown Food Research Centre, Ashtown, \\ Dublin D15 KN3K, Ireland; Stephen.Bleakley@teagasc.ie \\ 2 School of Biological Sciences, College of Sciences and Health and Environment, Sustainability and \\ Health Institute, Dublin Institute of Technology, Kevin Street, Dublin D08 NF82, Ireland \\ * Correspondence: Maria.Hayes@teagasc.ie; Tel.: +353-1-805-9957
}

Academic Editor: Christopher J. Smith

Received: 21 March 2017; Accepted: 20 April 2017; Published: 26 April 2017

\begin{abstract}
Population growth combined with increasingly limited resources of arable land and fresh water has resulted in a need for alternative protein sources. Macroalgae (seaweed) and microalgae are examples of under-exploited "crops". Algae do not compete with traditional food crops for space and resources. This review details the characteristics of commonly consumed algae, as well as their potential for use as a protein source based on their protein quality, amino acid composition, and digestibility. Protein extraction methods applied to algae to date, including enzymatic hydrolysis, physical processes, and chemical extraction and novel methods such as ultrasound-assisted extraction, pulsed electric field, and microwave-assisted extraction are discussed. Moreover, existing protein enrichment methods used in the dairy industry and the potential of these methods to generate high value ingredients from algae, such as bioactive peptides and functional ingredients are discussed. Applications of algae in human nutrition, animal feed, and aquaculture are examined.
\end{abstract}

Keywords: seaweed; microalgae; peptides; phycobiliproteins; biorefinery; bioavailability; extraction methods; legislation

\section{Introduction}

The global population is expected to increase by over a third ( 2.3 billion people) by 2050 , requiring an estimated $70 \%$ increase in food production [1]. A combination of improved agricultural food production methods and an increase of average per capita income have led to a decrease in global hunger over the last half-century, despite a doubling of the world's population [1]. However, worldwide food production is now facing a greater challenge than ever before. Previously utilised methods of intensifying agriculture will soon no longer be an option due to the high impact trade-offs they have on the environment, including fragmenting natural habitats and threatening biodiversity, production of greenhouse gases from land clearing, fertilisers and animal livestock production, and nutrient run-off from fertiliser damaging marine, freshwater and terrestrial ecosystems [2]. In particular, protein is one of the main nutrients that will be in short supply in the future. Alternative protein sources and production methods are required to fulfil the demand of consumers and to meet predicted global protein requirements.

Seaweed and microalgae are considered a viable source of protein. Some species of seaweed and microalgae are known to contain protein levels similar to those of traditional protein sources, such as meat, egg, soybean, and milk [3,4]. Algae use for protein production has several benefits over traditional high-protein crop use in terms of productivity and nutritional value. Seaweed and microalgae have higher protein yield per unit area (2.5-7.5 tons/Ha/year and 4-15 tons/Ha/year, respectively) compared to terrestrial crops, such as soybean, pulse legumes, and 
wheat (0.6-1.2 tons/Ha/year, 1-2 tons/Ha/year, and 1.1 tons/Ha/year, respectively) [5]. Terrestrial agriculture already requires approximately $75 \%$ of the total global freshwater with animal protein in particular requiring 100 times more water than if the equivalent amount of protein was produced from plant sources [6,7]. Marine algae do not require freshwater or arable land to grow, maximising resources that can be used for additional food production or other cash crops [5]. Furthermore, due to their harsh environment and phototropic life, algae are often exposed to high oxidative and free-radical stresses [8]. This has led to the evolution of natural protective systems, such as the production of pigments (e.g., carotenes, chlorophylls, and phycobiliproteins) and polyphenols (e.g., catechins, flavonols, and phlorotannins), which can impart health benefits to the consumer when eaten $[9,10]$.

However, widespread use of seaweed and microalgae is limited by a number of factors including; harvesting access and rights, seasonality and geographical location of algae, as well as the availability of scalable production methods for protein isolation from algae. Current processes of algal protein isolation are time-consuming and economically unviable [11]. The objective of this paper is therefore to discuss the value of algal proteins as a source of human nutrition, functional foods and animal feed, as well as describe current extraction methods and novel processing technologies that are used in dairy processing which may be employed to make algae a viable source of protein ingredients.

\subsection{Characteristics of Seaweed}

Algae are a diverse group of species which can be broadly described as oxygen-producing, photosynthetic, unicellular or multicellular organisms excluding embryophyte terrestrial plants and lichens [12]. Macroalgae can be divided into three main taxonomic groups based on their pigmentation; Phaeophyta (brown algae), Chlorophyta (green algae), and Rhodophyta (red algae) [13].

According the Food Balance sheets published by the Food and Agriculture Organisation of the United Nations (FAO), the Republic of Korea is the greatest consumer of seaweed (22.41 kg/capita/year in 2013), followed by China and Japan [14]. Production of farmed seaweed has more than doubled worldwide since 2000, with particular expansion seen in Indonesia due to their vast areas of shallow sunlight coasts suitable for culture sites [15]. The culture of Japanese kelp, Laminaria japonica, has traditionally been the most extensively farmed cold-water species. This was surpassed by the tropical Eucheuma seaweeds (Kappaphycus alvarezii and Eucheuma spp.) in 2010. The other most commonly farmed seaweed species are Gracilaria spp., Undaria sp., and Porphyra spp. [15].

Brown algae are distinguished by the presence of the pigment fucoxanthin, which is responsible for the distinctive olive-brown colour that lends this group its name [13]. Brown algae are also unique among algae as they are only found in multicellular form [16]. There are approximately 1500-2000 species of brown algae worldwide [17]. Some species, such as Macrocystis pyrifera (giant kelp), play an important role in the ecosystem, growing up to $20 \mathrm{~m}$ and forming underwater kelp forests [18]. There are also many other species that have been exploited for human consumption, including Undaria pinnatifida (wakame), Hizikia fusiformis (hijiki), and Laminaria japonica (kombu) [19]. Several types of brown algae are used for animal feed, including Laminaria digitata (oarweed), Ascophyllum nodosum (rockweed) and Fucus vesiculosus (bladder wrack) [3].

Green algae are a diverse group of approximately 8000 species, consisting of the divisions Chlorophyta and Charophyta [20]. Chlorophyta are a large group of unicellular and multicellular algae, while charophyta are a smaller group of exclusively freshwater, multicellular green algae from which it is believed that Embryophyta (terrestrial plants) evolved from [21]. Green algae obtain their pigmentation from chlorophyll $a$ and $b$, as well as other pigments including $\beta$-carotene and xanthophylls [13]. The most commonly consumed species of green algae are Ulva spp. including $U$. lactuca (sea lettuce), U. intestinalis, and $U$. compressa.

Red algae are a large group of mostly multicellular macroalgae with approximately 6000 species [13]. Red algae are characterised by the presence of phycobilins, which are responsible for their red colour [13]. Species of Irish moss, such as Chondrus crispus and Mastocarpus stellatus, are exploited for their production of carrageenan [22]. Other species of red algae, including Porphyra tenera 
(nori) and Palmaria palmata (dulse), are among the highest consumed species of seaweed in Asia, as well as Western countries, due to their high protein content and their delectable flavour [23]. In particular, Porphyra tenera is used in the production of sushi.

\subsection{Characteristics of Microalgae}

Microalgae are unicellular, microscopic organisms that are also considered as a viable alternative protein source. The most abundant microalgal divisions are Bacillariophyta (diatoms), Chlorophyta (green algae), Chrysophyta (golden algae), and Cyanophyta (blue-green algae). Microalgae are a hugely diverse group containing approximately 200,000 species [24]. Several of these species are currently exploited for a variety of biotechnological purposes, including cosmeceuticals, animal feed, fatty acids, alginates, wastewater treatment, and biofuel $[9,25,26]$. Furthermore, Arthrospira platensis (Spirulina), and Chlorella vulgaris (Chlorella) are also sold as functional foods due to their high vitamin and mineral content and as they are generally regarded as safe (GRAS) by the European Food Safety Authority (EFSA) [25]. Despite the relatively low quantity of microalgae produced annually compared to that of seaweed (5000 tonnes dry matter per year versus $7.5 \times 10^{6}$ tonnes dry matter per year, respectively), whole microalgal biomass and added-value compounds are economically valuable, representing a global turnover of about US $\$ 1.25 \times 10^{9}$ per year, compared to annual seaweed turnover of US $\$ 6 \times 10^{9}[9]$.

Arthrospira platensis is a filamentous Cyanobacterium that has among the highest recorded protein content of any whole food [27]. Arthrospira sp. was originally referred to as Spirulina sp. until a re-examination showed that they are actually a distinct genus [9]. However, due to its widely publicised use as a food and dietary supplement, the term Spirulina is often used interchangeably with Arthrospira.

Chlorella spp. are spherical members of the phylum Chlorophyta (green algae) that have also seen increased popularity as a food supplement in recent times. Chlorella vulgaris is the most commonly exploited industry species due to its high protein content ( $51 \%-58 \%$ dry weight; $\mathrm{dw}$ ) and favourable essential amino acid composition [28]. Chlorella also contains many other beneficial nutrients, including $\beta$-1,3-glucan, vitamins (B-complex and ascorbic acid), minerals (potassium, sodium, magnesium, iron, and calcium), $\beta$-carotene, chlorophyll, and Chlorella growth factor (CGF) [29].

\section{Protein Quality}

\subsection{Amino Acid Composition}

The quality of proteins can vary dramatically, depending on digestibility and the availability of essential amino acids [30]. Animal sources of protein are generally considered as complete proteins, as they are a rich source of essential amino acids (EAAs) which the human body is unable to biosynthesise. Alternatively, plant proteins are often considered an incomplete protein source as they commonly lack one or more of the essential amino acids, including histidine, isoleucine, leucine, lysine, methionine, phenylalanine, threonine, tryptophan, and valine [31]. However, the lacking essential amino acid(s) in plant-based proteins can differ, meaning that an individual should be able to obtain a sufficient quantity of all essential amino acids if they consume a varied diet of plant proteins from fruit, vegetables, grains, and legumes [32]. Plant-based proteins are also typically harder to digest than animal proteins, due to their high concentration of insoluble polysaccharides. Despite this, there are increasing concerns about the high levels of saturated fats and cholesterol found in foods of animal origin, which are linked to the development of cardiovascular disease and diabetes. This has led to nutritionists and organisations, such as the FAO, recommending a more varied diet rich in plant-based proteins [33].

Algae are generally regarded as a viable protein source, with EAA composition meeting FAO requirements and they are often on par with other protein sources, such as soybean and egg $[3,33]$. The lack of widespread consumption of marine algae has led to a shortage of in vivo research regarding the ileal digestion of algae, thus limiting the comparison of algal protein quality between different 
algae species, as well as with other protein sources [34]. Nevertheless, tryptophan and lysine are often limiting amino acids in most algae species [35-37]. Furthermore, leucine and isoleucine are commonly found in low concentrations in red species of algae, while methionine, cysteine, and lysine are often limiting in brown algae species $[35,38]$. Cysteine typically occurs at low levels in many seaweed species, and is often not detectable [39]. Aspartic acid and glutamic acid constitute a relatively large proportion of the total amino acids in many seaweed species, largely contributing to the distinctive 'umami' taste associated with seaweed [40]. For example, these two amino acids have been reported to represent $22 \%-44 \%$ of total amino acids in Fucus sp. and $26 \%-32 \%$ in Ulva sp. [3].

\subsection{Algal Protein Digestibility}

Bioavailability can be described as the fraction of ingested food components that is available at the target site of action for utilisation in various physiological functions [41]. Bioavailability entails the entire process following food element consumption, including digestibility and solubility of the food element in the gastrointestinal tract, absorption/assimilation of the food element across the intestinal epithelial cells and into the circulatory system, and finally, incorporation into the target site of utilisation (Figure 1) [42]. Studies examining the bioavailability of food elements are therefore required to incorporate in vivo experiments. One in vivo study evaluated the bioavailability of $P$. tenera and $U$. pinnatifida in Wistar rats, which reported that the fibre in seaweed had a negative impact on protein intake digestibility and food efficiency [43]. Similarly, L. japonica was also reported to decrease protein digestibility in rats, although interestingly, digestibility ended up being comparable with the control diet after 3 weeks as the rats appeared to adapt to the high fibre diet [44]. It is thought that phlorotannins and high polysaccharide content are the main factors which negatively impact the digestibility of algal proteins $[45,46]$.

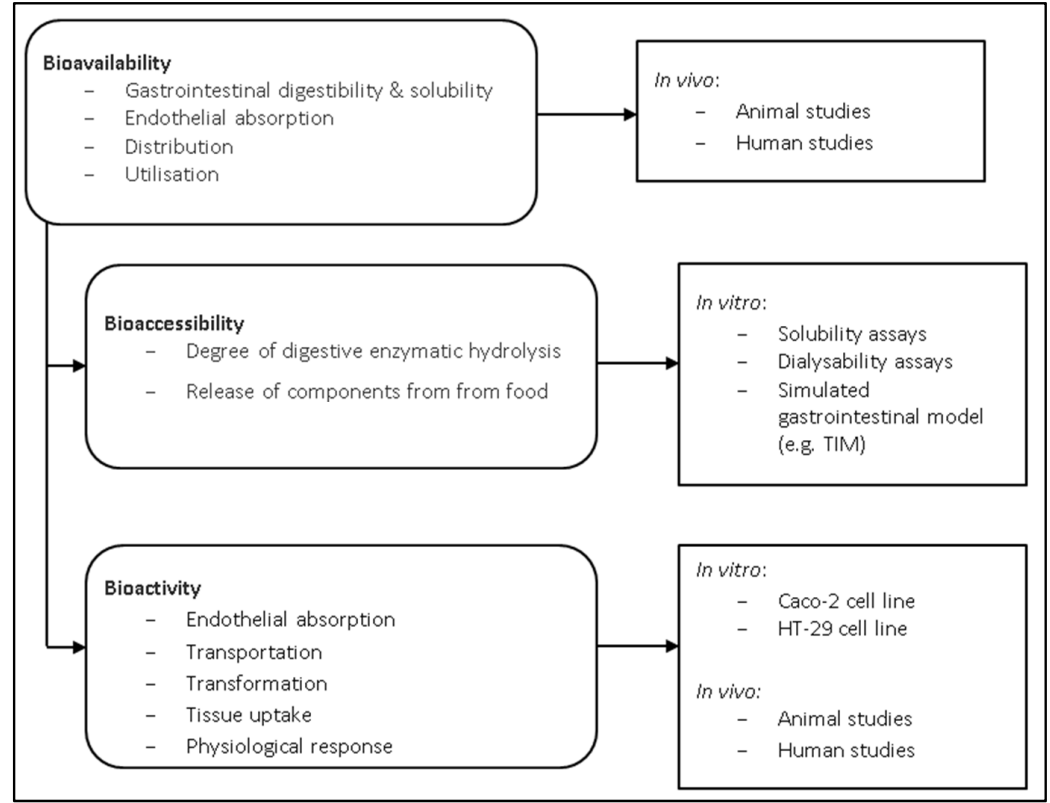

Figure 1. Schematic representation of digestion and methods that may be used to determine bioavailability, bio-accessibility and bioactivity of proteins and other foods. Adapted from Carbonell-Capella et al. [47]. TIM: TNOASR's intestinal model; TNOASR: The Netherlands Organization for Applied Scientific Research.

Bioavailability can be further divided into two different stages; bioaccessibility and bioactivity. Bioaccessibility involves examining the fraction of particular components that are released from the whole food matrix within the gastrointestinal tract in order to identify elements that are accessible 
for further absorption [48]. Bioactivity refers to the assimilation of a food elemen14 $t$ across intestinal cells, transport of the element to the target site, interaction of the element with the target site, any necessary biotransformation of the food element, and the physiological response created as a result of incorporation of the element with the target site (Figure 1) [49]. There are many factors affecting digestibility which can make in vitro studies difficult, including the macronutrient composition, enzyme specificity, anti-nutritional factors, fibre, and varying absorptive capacities at different stages within the gastrointestinal tract [30]. Nevertheless, in vitro studies serve as a useful preliminary screening tool to identify promising food matrices, growing conditions, and processing methods [48,50,51].

Methods for assessing in vitro digestibility are typically divided into four categories, including solubility, dialysability, gastrointestinal chambers, and cell models [48]. Only small, soluble molecules can be absorbed in the small intestine, which can be evaluated by methods such as atomic absorption spectrophotometry, mass spectrometry, or high-performance liquid chromatography [48]. Dialysability is a direct measure of a food components ability to cross a membrane, although dialysability assays have typically been carried out on micronutrients, including iron, zinc, magnesium and calcium [52].

Bioaccessibility in vitro studies are typically accomplished using either static or dynamic measuring systems. Static systems are the more basic of the two, measuring the release of free amino acids from dietary proteins following hydrolysis from gastrointestinal enzymes under discrete $\mathrm{pH}$ and temperature [49]. Static systems have the advantage of being easily implemented, low cost, and high throughput, but have the disadvantage of being unrealistic for normal gastrointestinal physiological processes. Alternatively, dynamic systems use computer systems to tightly regulate $\mathrm{pH}$, temperature, enzyme addition, mixing and residence times within chambers in order to more closely mimic gastrointestinal digestion [48]. These systems model gastric physiology more accurately, but have the drawbacks of being costly and low throughput, limiting their routine use.

The Netherlands Organization for Applied Scientific Research (TNOASR) has developed two similar dynamic gastrointestinal models, called TNOASR's intestinal model (TIM-1 and TIM-2) [48]. The TIM-1 system contains several compartments used to mimic the effect of the stomach and small intestine (including duodenum, jejunum, and ileum) [53]. TIM-2 focuses on the large intestine, serving as a tool to study the effect of microbial fermentation and nutrient absorption in the colon [54]. In both models, aliquots can be taken from any chamber at any given time [48]. Additional in vitro gastrointestinal models have also been described to study digestion and microbiota colonisation [55-58]. However, one such issue that plagues digestibility studies is the lack of consistency occurring in differing methodologies, making the resulting data difficult to compare [59]. INFOGEST is an action granted by the European Cooperation in Science and Technology (COST) and was developed to help overcome this hurdle. INFOGEST is a static in vitro digestion model which aims to harmonise the methods used to assess digestibility, allowing for better comparisons between studies $[60,61]$.

Various in vitro cell culture methods have been utilised to simulate a food component's ability to be assimilated within the intestine, the first component within bioactivity (Figure 1). Caco-2 cells, a cell line derived from human colonic adenocarcinoma, are by far the most commonly used [52,62]. HT-29 is another human colon carcinoma cell line that has been used to study epithelial transport, although it is rarely used [63]. The co-culture of Caco-2 cells with a human mucous-producing cell line, such as HT29-MTX, has been suggested to more closely resemble in vivo conditions [64].

Similar to the previously described in vivo protein quality studies [43,44], in vitro bioaccessibility studies also appear to suggest that unprocessed seaweed proteins have reduced digestibility compared to that of other protein sources. For example, the seaweed species P. tenera, U. pinnatifida, and Ulva pertusa have reported in vitro bioaccessibility of $78 \%, 87 \%$, and $95 \%$, respectively, expressed as a percentage of casein bioaccessibility (100\%) [3]. U. lactuca has been shown to have an in vitro digestibility of $85.7 \% \pm 1.9 \%$, while the red seaweeds Hypnea charoides and H. japonica have high digestibility of $88.7 \% \pm 0.7 \%$ and $88.9 \% \pm 1.4 \%$, respectively [65]. Comparable results for $U$. lactuca were found with in vitro simulated ileal digestibility of $82.3 \%$ [66]. Tibbetts and colleagues (2016) reported significantly greater in vitro digestibility in red seaweeds $(83 \%-87 \%)$ compared to brown 
seaweeds (78.7\%-82\%) [67]. These results demonstrate that seaweed proteins have comparable in vitro digestibility compared to that of other commonly consumed plants, including grains $(69 \%-84 \%)$, legumes $(72 \%-92 \%)$, fruits $(72 \%-92 \%)$, and vegetables (68\%-80\%) [67].

The digestibility of microalgae is poorly examined within the literature, including in vitro bioaccessibility studies. However, microalgae appear to have similar digestibility to that of seaweed, with Scenedesmus obliquus, Spirulina sp., Chlorella sp. having digestibility coefficient values of $88.0 \%$, $77.6 \%$, and $76.6 \%$, respectively [28]. This is in comparison to protein sources such as casein and egg with a digestibility coefficient of $95.1 \%$ and $94.2 \%$.

\section{Protein Extraction Methods}

\subsection{Conventional Protein Extraction Methods}

Seaweed and microalgae have poor protein digestibility in their raw, unprocessed form and it is for this reason that great emphasis has been placed on developing improved methods for algal protein extraction in order to improve their bioavailability. Algal proteins and their extraction is a relatively poorly studied topic compared to proteins from other crops [68]. Algal proteins are conventionally extracted by means of aqueous, acidic, and alkaline methods, followed by several rounds of centrifugation and recovery using techniques such as ultrafiltration, precipitation, or chromatography [69]. Chemical extraction methods, such as two-phase acid and alkali treatments, have been especially efficient for extracting proteins from A. nodosum, Ulva spp. and L. digitata (Table 1) [69-71].

However, the successful extraction of algal proteins can be greatly influenced by the availability of the protein molecules, which can be substantially hindered by high viscosity and anionic cell-wall polysaccharides, such as alginates in brown seaweed and carrageenans in red seaweed [72]. Cell disruption methods and the inclusion of selected chemical reagents are therefore used in order to improve the efficiency of algal protein extraction. Some examples of conventional methods that are commonly utilised include mechanical grinding, osmotic shock, ultrasonic treatment, and polysaccharidases-aided hydrolysis (Table 1) [73].

Table 1. Conventional pre-treatment cell disruption methods and extraction methods for precipitating proteins from seaweed. Dry weight; dw.

\begin{tabular}{|c|c|c|c|c|c|}
\hline $\begin{array}{l}\text { Extraction } \\
\text { Method }\end{array}$ & Species & Extraction Name & Reagents & Protein Yield & Reference \\
\hline \multirow{3}{*}{$\begin{array}{l}\text { Enzymatic } \\
\text { hydrolysis }\end{array}$} & Palmaria palmata & $\begin{array}{l}\text { Polysaccharidase } \\
\text { degradation }\end{array}$ & $\begin{array}{l}\left.\text { Cellulase (Cellucast }{ }^{\circledR}\right) \text { and } \\
\text { xylanase }\left(\text { Shearzyme }{ }^{\circledR} \text { ) }\right.\end{array}$ & $\begin{array}{l}\text { Factor } 3.3 \text { compared to } \\
\text { control }\end{array}$ & [46] \\
\hline & $\begin{array}{l}\text { Chondrus crispus, } \\
\text { Gracilaria verrucosa, }\end{array}$ & $\begin{array}{l}\text { Polysaccharidase } \\
\text { degradation }\end{array}$ & $\begin{array}{l}\text { к-carrageenase, } \beta \text {-agarase, } \\
\text { xylanase, cellulase }\end{array}$ & - & [74] \\
\hline & Palmaria palmata & $\begin{array}{l}\text { Polysaccharidase } \\
\text { degradation }\end{array}$ & $\begin{array}{l}\text { Cellulase }\left(\text { Cellucast }^{\circledR}\right) \text {, } \\
\text { xylanase }\left(\text { Shearzyme }{ }^{\circledR}\right) \text { and } \\
\text { Ultraflo }^{\circledR}(\beta \text {-glucanase })\end{array}$ & $\begin{array}{l}11.57 \pm 0.08 \mathrm{~g} / 100 \mathrm{~g} \mathrm{dw} \\
(67 \% \text { yield })\end{array}$ & [73] \\
\hline \multirow{2}{*}{$\begin{array}{l}\text { Physical } \\
\text { Process }\end{array}$} & $\begin{array}{l}\text { Porphyra acanthophora } \\
\text { var. acanthophora, } \\
\text { Sargassum vulgare } \\
\text { and Ulva fasciata }\end{array}$ & $\begin{array}{l}\text { Aqueous treatment } \\
\text { and Potter } \\
\text { homogenisation }\end{array}$ & Ultra-pure water & $\begin{array}{l}8.9 \mathrm{~g} / 100 \mathrm{~g} \mathrm{dw}, \\
6.9 \mathrm{~g} / 100 \mathrm{~g} \mathrm{dw}, \\
7.3 \mathrm{~g} / 100 \mathrm{~g} \mathrm{dw}\end{array}$ & [68] \\
\hline & Palmaria palmata & Osmotic stress & - & $\begin{array}{l}6.77 \pm 0.22 \mathrm{~g} / 100 \mathrm{~g} \mathrm{dw} \\
(39 \% \text { yield })\end{array}$ & [73] \\
\hline \multirow{4}{*}{$\begin{array}{l}\text { Chemical } \\
\text { extraction }\end{array}$} & Ascophyylum nodosum & $\begin{array}{l}\text { Acid-alkaline } \\
\text { treatment }\end{array}$ & $0.4 \mathrm{M} \mathrm{HCl}$ and $0.4 \mathrm{M} \mathrm{NaOH}$ & $59.76 \%$ yield & [69] \\
\hline & $\begin{array}{l}\text { Ulva rigida } \\
\text { Ulva rotunda }\end{array}$ & Two-phase system & $\mathrm{NaOH}$ and 2-mercaptoethanol & - & [70] \\
\hline & Laminaria digitata & Two-phase system & $\begin{array}{l}\text { Polyethylene glycol (PEG) and } \\
\text { potassium carbonate }\end{array}$ & - & [71] \\
\hline & Palmaria palmata & $\begin{array}{l}\text { Alkaline and } \\
\text { aqueous }\end{array}$ & $\begin{array}{l}\mathrm{NaOH} \text { and } \mathrm{N} \text {-acetyl- } \\
\text { L-cysteine (NAC) }\end{array}$ & $\begin{array}{l}4.16 \mathrm{~g} / 100 \mathrm{~g} \mathrm{dw} \\
(24 \% \text { yield })\end{array}$ & [73] \\
\hline
\end{tabular}




\subsubsection{Physical Processes}

Barbarino and Lourenço (2005) reported that physical grinding with the use of a Potter homogeniser significantly increased protein extraction yield from Porphyra acanthophora var. acanthophora, Sargassum vulgare, and Ulva fasciata following immersion in ultra-pure water (Table 1) [68]. Alternatively, osmotic stress has also been reported to improve extraction of algal proteins efficiency $[45,75]$. Osmotic shock was reported to yield a significantly higher concentration of water soluble proteins from P. palmata $(1.02 \pm 0.07 \mathrm{~g} / 100 \mathrm{~g})$ compared to high shear force with an Ultra-turrax ${ }^{\circledR}$ T25 Basic tool (IKA ${ }^{\circledR}$, Staufen, Germany) $(0.74 \pm 0.02 \mathrm{~g} / 100 \mathrm{~g})$ [73]. However, there was no significant difference in the amount of total protein extracted between the two methods (6.77 versus $6.92 \mathrm{~g} / 100 \mathrm{~g}$ ). Alternatively, the use of polysaccharidases was reported to be a more promising method of protein extraction, with a concentration of $11.57 \pm 0.08 \mathrm{~g} / 100 \mathrm{~g}$ P. palmata, equating to a yield of $67 \%$ (Table 1) [73].

\subsubsection{Enzymatic Hydrolysis}

Seaweed is rich in several types of polysaccharides, including cellulose, galactans, xylans, fucoidan, laminarin, alginates, carrageenans, and floridean starch [22]. These polysaccharides can reduce the availability of algal proteins and decrease protein extraction efficiency [68]. Enzymes such as polysaccharidases can therefore be applied as a cell disruption treatment prior to protein extraction in order to increase protein yield (Table 1 ). Several polysaccharidases ( $k$-carrageenase, $\beta$-agarase, xylanase, cellulase) were used in protein extractions from the red seaweed species $C$. crispus, Gracilaria verrucosa, and P. palmata as a method of combating the tough cell wall [74]. Hydrolysis of C. crispus with carrageenase and cellulase increased protein yield ten-fold compared to the enzyme-free procedure, while the highest yield from P. palmata was obtained with xylanase. Similarly, hydrolysis of $P$. palmata with xylanase and cellulase was demonstrated to yield a ten-fold increase in the phycoerythrin pigment protein compared to mechanical extraction [46]. Harnedy and Fitzgerald (2013) also increased protein yield from P. palmata with xylanase, although they reported that the high enzyme:substrate concentration required $\left(48.0 \times 10^{3}\right.$ units $\left./ 100 \mathrm{~g}\right)$ may not be commercially feasible at an industrial scale. Combining multiple extraction methods may also help to improve algal protein extraction. Combining enzymatic hydrolysis with alkaline extraction increased protein yield 1.63-fold compared to alkaline extraction alone in P. palmata [76].

\subsection{Current Protein Extraction Methods}

Protein extraction methods used on algae to date are limited for commercial use due to concerns with up-scaling. Conventional mechanical and enzymatic methods for protein extraction may also affect the integrity of extracted algal proteins due to the release of proteases from cytosolic vacuoles [77]. Furthermore, these methods are also laborious and time consuming [69]. Improved extraction methods of cell disruption and extraction are therefore required. Pre-treatment with cell-disruption techniques aid the breakdown of the tough algal cell wall, increasing the availability of proteins and other high-value components for later protein extraction. Some examples of novel protein extraction methods include ultrasound-assisted extraction, pulsed electric field, and microwave-assisted extraction [13].

\subsubsection{Ultrasound-Assisted Extraction}

Ultrasound-assisted extraction (UAE) can be applied to food sources for a number of applications, including modification of plant micronutrients to improve bioavailability, simultaneous extraction and encapsulation, quenching radical sonochemistry to avoid degradation of bioactives, and increasing bioactivity of phenolics and carotenoids by targeted hydroxylation [78]. The degradative effect of radical sonochemistry, which is the most relevant aspect in terms of improving bioavailability of algal proteins, is not produced by the ultrasound waves, but rather by the formation, growth, and implosion of bubbles formed by what is known as acoustic cavitation [79]. The violent implosion of these bubbles 
creates microscopic regions of extreme pressure and temperature, resulting in the chemical excitation of the sonicated liquid and its contents, facilitating the particle breakdown and degradation of the target compound [80]. The major advantages of UAE are its fast processing time, non-thermal properties, and low solvent consumption, resulting in a higher purity final product with reduced downstream processing required [81].

Ultrasound pre-treatment was reported to increase protein extraction of Ascophyllum nodosum with acid and alkaline treatment alone by $540 \%$ and $27 \%$, respectively, as well as reduce processing time from $60 \mathrm{~min}$ to $10 \mathrm{~min}$ [69]. This dramatic increase in protein yield was suggested to be due to acid hydrolysis alone being insufficient to erode the tough cell wall. Ultrasound-aided extraction was also evaluated in microalgae for a number of value-added components, although there have been relatively few studies that have focused on ultrasound for improved protein extraction [82,83]. Keris-Sen and colleagues (2014) reported that ultrasound at a power intensity of $0.4 \mathrm{kWh} \cdot \mathrm{L}^{-1}$ yielded the optimum concentrations of proteins from wastewater treatment microalgae from the Chlorococcales order of the Chlorophyceae class (e.g., Scenedesmus sp.) [84]. Ultrasound treatment of C. vulgaris significantly increased crude protein digestibility in rats compared to electroporated and untreated spray-dried C. vulgaris $(56.7 \% \pm 13.7 \%, 44.3 \% \pm 7.5 \%$, and $46.9 \% \pm 12.7 \%$, respectively), as well as significantly improving protein efficiency ratio and nitrogen balance [85]. Additionally, there were no adverse effects to the histology of major organs upon prolonged consumption of ultrasound-treated microalgae, and thus it has been suggested as a viable pre-treatment method for the food industry [86]. Alternating two counter-current frequencies has also been suggested as a viable method for further improving protein extraction, as demonstrated by a 50\% increase in yield and 18\% reduction in extraction time using 15 and $20 \mathrm{kHz}$ in Porphyra yezoensis compared to mono-frequency ultrasound-assisted extraction [87].

\subsubsection{Pulsed Electric Field}

Pulsed electric field (PEF) has been used as a cell disruption technique in microalgae, although its primary use has thus far been for the extraction of lipids for conversion to biofuel [88]. PEF involves applying high electric currents in order to perforate a cell wall or cell membrane, causing reversible or irreversible electroporation [88]. Electroporation enables the introduction of various foreign components to cells, including DNA, proteins, and drugs [89]. PEF is a fast and green technology for inactivating microorganisms by irreversible electroporation and aiding the release of intracellular contents of plant cells [90,91]. However, conductivity and electrode gap are factors that could possibly limit this technology for up-scaling [92].

Goettel and colleagues (2013) were among the first to report the use of PEF as a means of extracting multiple intracellular components from algae [93]. Since then, PEF has been demonstrated to increase the yield of several high-value microalgae components, including lipids, carbohydrates, carotenoids and chlorophyll [94-98]. Protein yield from Chlorella sp. and Spirulina sp. was reported to increase by $27 \%$ and $13 \%$, respectively, following PEF-treatment at $15 \mathrm{kV} / \mathrm{cm}$ and $100 \mathrm{~kJ} / \mathrm{kg}$ [99]. Coustets and colleagues (2013) also reported significantly increased protein extraction in C. vulgaris and Nannochloropsis salina following PEF-assisted extraction, allowing for the extraction of intact cytosolic proteins [100].

\subsubsection{Other}

Microwave-assisted extraction (MAE) involves heating a material, causing moisture to evaporate, thus creating bubbles under high pressure which can then rupture to disrupt cell contents [82]. Increased levels of soluble proteins were extracted from a microalgae biomass containing green microalgae (Stigeoclonium sp. and Monoraphidium sp.) and diatoms (Nitzschia sp. and Navicula sp.) using microwave pre-treatment compared to ultrasound [101]. MAE has attracted attention for extraction of compounds due low energy efficiency, although its use in algae may be limited by impaired function with dried samples [81]. 
Alternatively, sub- and supercritical fluid extraction techniques have gained popularity in recent decades as extraction methods. Subcritical water extraction (SWE) involves using hot water (100-374 $\left.{ }^{\circ} \mathrm{C}\right)$ under high pressure ( 10 bar) to maintain water in a liquid state [102]. Alternatively, supercritical fluid extraction (SFE) is a technique that heats a fluid above its critical point, making it supercritical. Under supercritical conditions, the properties of the fluid become indistinguishable from its gaseous state, with a density similar to a fluid, but viscosity matching that of gas [102]. SFE typically utilises carbon dioxide $\left(\mathrm{CO}_{2}\right)$, making it a relatively 'green' technology with low solvent consumption [81]. However, SWE and SFE both require high investment costs for equipment and have typically only been used in algae to date for the extraction of lipids [102].

\subsection{Enrichment Methods—Membrane Filtration}

Membrane technologies are widely used in the dairy industry to recover whey proteins from milk released as a result of the cheese-making process [103]. Membrane technology refers to the use of a semi-permeable membrane to separate a liquid into two different fractions by selectively allowing some compounds to pass through while impeding other compounds, typically based on molecular weight. Membrane technologies are promising alternative methods of enriching algal proteins, as well as developing novel techno-functional and bioactive ingredients. They have the advantage of being non-thermal and environmentally-friendly [103]. The most commonly used membrane technologies include microfiltration, ultrafiltration, nanofiltration, and reverse osmosis.

Membrane technologies could act as an alternative method for enriching algal proteins when used in conjunction with a cell disruption technique, such as polysaccharidase hydrolysis, UAE, or PEF. Disruption of the tough cell wall is a critical step required in order to increase the availability of algal proteins for extraction [82]. Membrane technologies are well suited for use with seaweed as part of a cascading biorefinery process to maximise valorisation of all components within algae, while avoiding the presence of heavy metals in the final product [104]. A combination of membrane technologies could be used to isolate algal proteins using the same principles of molecular weight cut-offs used in the dairy industry. In the dairy industry, microfiltration (MF) is used to extend the shelf-life of milk without any thermal treatment by removing microorganisms, while preserving overall taste and sensory attributes [105]. MF could be used to remove algae cell wall components and bacteria with a molecular weight greater than $200 \mathrm{kDa}$. Ultrafiltration (UF) could then be used to isolate proteins and other macromolecules between 1 and $200 \mathrm{kDa}$, similar to the way it is used in the dairy industry to generate enriched fractions less than 10,5, 3 and $1 \mathrm{kDa}$. Nanofiltration (NF) could then be used to remove monovalent salts to minimise osmotic pressure, followed by reverse osmosis (RO) to reduce fluid volume [103].

Indeed, membrane technologies have already been used to isolate whole microalgae cells and several seaweed components. Tangential flow microfiltration was reported as an efficient method for recovering $70 \%-89 \%$ of algal biomass from wastewater treatments [106]. UF was previously used in conjunction with supercritical $\mathrm{CO}_{2}$ extraction and ultrasound to isolate Sargassum pallidum polysaccharides [107]. Polysaccharides with antioxidant activities were isolated from $U$. fasciata utilising hot water extraction followed by several stages of ultrafiltration with increasingly smaller pore sizes [108]. Furthermore, UF was used to isolate phycoerythrin protein from Grateloupia turuturu following cell homogenisation, which was reported to retain $100 \%$ of the protein without denaturation [109]. Alternatively, a two-stage ultrafiltration could be applied for algal protein enrichment, as demonstrated by the separation of polysaccharide components in Tetraselmis suecica using different sized pore membranes following high-pressure homogenisation [110]. 


\section{Applications}

\subsection{Human Nutrition}

Protein is an essential nutritional component in the diet of athletes, required to repair and build muscle tissue broken down during exercise, with the American College of Sports and Medicine recommending between 1.2 and $1.7 \mathrm{~g}$ protein per $\mathrm{kg}$ body weight [111]. Seaweed and microalgae are rich sources of protein and contain all of the essential amino acids at various concentrations [112]. Algae could therefore represent a valuable resource for athletes requiring high levels of protein, especially for vegan athletes for whom eggs and dairy whey protein may not be suitable [113].

Seaweed and microalgae have been used as a source of human nutrition for thousands of years in some indigenous populations [114]. One of the main reasons for the high consumption of seaweed and microalgae is due to their significant protein content, which is comparable to, or even greater than, some plant sources [28]. Some species of red seaweeds (Rhodophyta), such as P. palmata and P. tenera, have been reported to contain as much as 33\% and $47 \% \mathrm{dw}$, respectively [3]. Similarly, some species of microalgae have been reported to contain even higher levels, as high as 63\% dw in Spirulina sp. [115]. Microalgae are typically consumed as a dietary supplement in the form of powder, pills, or tablets [9]. However, they have also been incorporated into a number of functional foods, including noodles, bread, biscuits, drinks, sweets, and beer [116]. Several businesses have been set up for the sale of algal products, such as AlgaVia ${ }^{\circledR}$ (www.algavia.com), which produces protein- and lipid-rich algal flour from Chlorella protothecoides.

There are several species of seaweed that have traditionally been consumed, largely due to their high protein content. For example, P. tenera (nori) is commonly used as a sushi wrap in several Asian cultures [22]. Many species of seaweed are particularly high in the amino acids aspartic acid and glutamic acid, which exhibit a unique and interesting flavour that led to the discovery of the taste sensation referred to as 'umami' [40]. The flavour enhancer monosodium glutamate was first discovered in the brown seaweed L. japonica (kombu), which has been found to particularly appeal to the umami taste sensation [117].

Although the consumption of seaweed in humans is currently underdeveloped, especially in Western countries, the high protein content and favourable essential amino acid profile makes seaweed a promising source of protein that is ripe for future expansion [40]. Seaweed has been successfully incorporated as a functional ingredient into several foods at the laboratory scale. U. pinnatifida (wakame) integrated into pasta has antioxidant activity and acceptable sensory attributes at levels up to $10 \%$ [118]. Bread containing $4 \%$ A. nodosum can significantly reduce energy intake in overweight individuals in the meal following enriched bread consumption [119]. Bread incorporating similar concentrations of renin-inhibitory peptides from P. palmata hydrolysates also had acceptable sensory attributes, with the bioactive properties reported as having survived the baking process [120].

Spirulina is the most highly consumed microalgae due to its high protein content and added nutritional benefits, including anti-hypertension, renal protective, anti-hyperlipidaemia, and anti-hyperglycaemic [121]. As well as being a rich source of proteins, Spirulina contains high levels of hypocholesterolemic $\gamma$-linoleic acid (GLA), B-vitamins, and free-radical scavenging phycobiliproteins [122]. It has therefore been given the label of a 'super food' by the World Health Organisation (WHO) and has even been sent to space by the National Aeronautics and Space Administration (NASA) due to its nutrient-dense properties [123]. As a demonstration of this, Spirulina has $180 \%$ more calcium than milk, $670 \%$ more protein than tofu, $3100 \%$ more $\beta$-carotene than carrots, and $5100 \%$ more iron than spinach [27]. The world's largest producer of Spirulina is Hainan Simai Enterprising Ltd., which is located in the Hainan province of China [121]. This cultivation farm produces an annual 200 tonnes dried biomass, accounting for $25 \%$ of the national output and a considerable $10 \%$ of the global production. Alternatively, the Earthrise Company has the largest Spirulina production plant, which is located in California, USA, and covers $440,000 \mathrm{~m}^{2}$ [121]. 
Chlorella is another widely consumed microalga, with global sales exceeding US $\$ 38$ billion [124]. The largest producer of Chlorella is Taiwan Chlorella Manufacturing and Co. (Taipei, Taiwan), which produces 400 tons dried biomass annually [121]. The main substance found in Chlorella that is beneficial for human health is $\beta-1,3$-glucan, which is an active immunostimulant, free-radical scavenger and reducer of blood lipids [125]. Chlorella is also rich in proteins $(48 \% \mathrm{dw})$, polyunsaturated fatty acids (PUFAs) (39\% of total lipids), and phosphorus (1761.5 mg/100g dw) [115].

\subsection{Industrial Applications}

Lectins and phycobiliproteins are two families of bioactive algal proteins which have been exploited for several industrial applications. Lectins are most commonly extracted from macroalgal sources, while phycobiliproteins are typically isolated from microalgae [126]. Phycobiliproteins, especially phycoerythrin, can constitute a significant proportion of the overall protein content in red algae, with levels of $1.2 \%$ (total $\mathrm{dw}$ ) reported for P. palmata [127]. Lectins are found at similar levels and a yield of 1\% lectins was obtained previously from Eucheuma serra (Rhodophyta) [128].

\subsubsection{Lectins}

Lectins are glycoproteins known for their aggregation and high specificity binding with carbohydrates without initiating modification through associated enzymatic activity [129]. Lectins are involved in several biological processes, including host-pathogen interactions, cell-cell communication, induction of apoptosis, cancer metastasis and antiviral activities [130]. Due to their carbohydrate binding capacity with high specificity, lectins are used in blood grouping, anti-viral (including human immunodeficiency virus type 1(HIV-1)), cancer biomarkers, and targets for drug delivery [131]. Lectins derived from algae have not received the same level of characterisation compared to other plant-derived lectins. Nevertheless, some of the bioactivities that have been observed in algal lectins include mitogenic, cytotoxic, antibacterial, anti-nociceptive, anti-inflammatory, anti-viral (HIV-1), platelet aggregation inhibition, and anti-adhesion [132].

\subsubsection{Phycobiliproteins}

Phycobiliproteins are water-soluble proteins with an important role in photosynthesis within cyanobacteria, Rhodophyta, and cryptomonads [133]. Phycobiliproteins are components of phycobilisomes, which are large light energy-capturing complexes anchored to thylakoid membranes [134]. There are four main divisions of phycobiliproteins which are grouped based on their colour and absorption characteristics, namely, phycoerythrin, phycocyanin, allophycocyanin, and phycoerythrocyanin [135]. The main commercial producers are Spirulina sp. (cyanobacterium) and Porphydrium sp. (Rhodophyta macroalgae) [121].

Phycobiliproteins are used in fluorescent labelling, flow cytometry, fluorescent microscopy, and fluorescent immunohistochemistry [136,137]. However, the primary commercial application of these phycobiliproteins appears to be as natural dyes, with phycocyanin in particular used as a blue pigment used in products such as chewing gum, popsicles, confectionary, soft drinks, dairy products, and wasabi, as well as cosmetic products, such as lipstick and eyeliner [121]. Several patents concerning health beneficial bioactivities of phycobiliproteins have also already been filed for nutraceutical applications such as anti-oxidative, anti-inflammatory, anti-viral, anti-tumour, neuroprotective, and hepatoprotective activities [135].

\subsection{Animal Feed}

The high protein content of algae can also be beneficial for use as animal feed, including aquaculture, farm animals, and pets. An estimated $30 \%$ of global algal production is estimated to be used for animal feed, with $50 \%$ of Spirulina biomass in particular used as feed supplement due to its excellent nutritional profile [124,138]. Several species of microalgae including Spirulina, Chlorella, and Schizochytrium sp., and seaweed including Laminaria sp. and Ulva sp. can be incorporated as 
protein sources into the diets of poultry, pigs, cattle, sheep, and rabbits [4,139]. Most of the research on the incorporation of algae as animal feed has been carried out with poultry, likely due to their promising prospects for improved commerciality [138].

Tasco ${ }^{\circledR}$ is an example of a proprietary seaweed meal derived from A. nodosum, produced by Acadian Seaplants in Nova Scotia, Canada (http://www.acadianseaplants.com), which has demonstrated beneficial properties when included in animal feed [140]. Tasco ${ }^{\circledR}$ has four main identified benefits for animal production, including resistance to stressors, improved immune system, increased productivity/quality, and a reduction in pathogenic microorganisms in the final meat product [141-144]. These benefits have been observed in several species, including monogastric and ruminant species, when at feed inclusion levels of $2 \%$ on a daily basis [145].

\subsubsection{Poultry}

Supplementing poultry feed with microalgae as a protein source can improve their health, productivity, and value. This has been demonstrated using a variety of species, including Chlorella sp., Arthrospira sp., Porphyridium sp., and Haematococcus sp. [86,139,146,147]. Chickens fed with supplemented Spirulina have been reported to have increased viability, improved overall health and reduced plasma concentrations of cholesterol, triglycerides, and fatty acids [148]. These birds also appeared to have an improved immune system as demonstrated by a significant increase in white blood cell count and enhanced macrophage phagocytic activity [148,149]. Ross and Dominy (1990) reported that feeding White Leghorn cockerel chicks, Hubbard by Hubbard male broiler chicks, and Japanese quail with varying concentrations of Spirulina in dietary feed slightly delayed growth rates, but did not affect final growth at concentrations less than 10\% [150]. Furthermore, this study also reported that the inclusion of Spirulina also increased fertility rates, as well as increasing the intensity of the egg-yolk colour [150]. These results have been confirmed by several other studies, indicating that the inclusion of Spirulina at a concentration of $2 \%-2.5 \%$ in the feed intensifies the colour of egg yolks to make it more esthetically pleasing for consumers [151,152]. The intensified colouration of the yolk is thought to be due to $\beta$-carotene [153]. The inclusion of Spirulina can also further valorise egg products by decreasing their cholesterol and saturated fatty acid content, and replacing it with increased levels of beneficial omega-3 polyunsaturated fatty acids [146,154].

Incorporation of $3 \% U$. lactuca in broiler chickens increased breast muscle yield compared to birds solely fed corn diet, as well as decreased serum lipids, cholesterol, and uric acid concentrations [155]. The red seaweed Polysiphonia spp. was also demonstrated to improve pellet binding in duck feed at concentrations of $3 \%$, as well as improve its overall nutrient profile [156]. The incorporation of red seaweeds C. crispus and Sarcodiotheca gaudichaudii was also reported to effectively act as a prebiotic to improve chicken gut health, productivity, and egg quality [157].

\subsubsection{Pigs}

The replacement of up to $33 \%$ of soy proteins with proteins from Arthrospira maxima, A. platensis, and C. vulgaris in pig feed has been reported as being suitable without any adverse effects [158]. The effect of feed processing appears to play a role in the utility of Spirulina in pig's feed. The addition of Spirulina to pellets was reported to decrease average daily gain, whereas incorporation of Spirulina to meal diets actually increased average daily gain [159]. Addition of Spirulina to the diet has also been suggested to improve fertility in pigs, increasing sperm motility and storage viability [160].

Supplementation of the brown seaweed L. digitata increased pig body weight gain by $10 \%$, as well as increase the concentration of iodine in fresh muscle by $45 \%$, thus increasing its valorisation [161]. Similarly, A. nodosum has also been reported to increase iodine content in pig tissue, while also increasing the concentrations of beneficial bacteria within the gut [162]. However, these results are in contrast to the findings of Reilly and colleagues (2008), who reported that the brown seaweeds Laminaria hyperborea and L. digitata actually decreased the biodiversity of beneficial microbial populations within the pig's gut, although this did not significantly affect the pig's performance [163]. 


\subsubsection{Ruminants}

Of all the animals evaluated for algae supplementation, ruminants are the most promising in terms of digesting the high fibre content for the greatest extraction efficiency of algal proteins [139]. This is in contrast to mono-gastric animals, for which it has been suggested that some form of prior processing may be required in order for animals (and humans) to utilise algal proteins more efficiently [164]. Cattle will preferentially drink water containing $20 \%$ suspended Spirulina, increasing their daily water intake by $24.8 \mathrm{~g} / \mathrm{kg}$ [165]. Furthermore, this study also reported that $20 \%$ of the consumed Spirulina bypasses degradation within the rumen, allowing for increased digestion and absorption of protein and nutrients within the abomasum [165]. Incorporation of $200 \mathrm{~g} /$ day Spirulina with cattle feed was reported to be an economically effective method of increasing animal body weight $(8.5 \%-11 \%)$ and daily milk production (21\%) [166]. As well as increasing milk quantity, Spirulina supplementation has also been demonstrated to increase milk quality by decreasing saturated fatty acids, while simultaneously increasing monounsaturated fatty acids and polyunsaturated fatty acids [167]. Similar results were observed in other studies, as well as with supplementation of Schizochytrium sp. [168,169].

Sheep have also been demonstrated to benefit from microalgae as a protein source, with lambs reported to have increased average daily gains upon consumption of $10 \mathrm{~g}$ of Spirulina per day [170]. Similarly, Spirulina diet supplementation increased the feed intake of rabbits, as well as improve the quality of rabbit meat with higher levels of GLA [171]. The green seaweed $U$. lactuca has been reported as a suitable low-energy, high-protein foodstuff for sheep and goats [172,173]. However, seaweed may be not be suitable for supplementation in pregnant ewes, having been reported to interfere with passive immunity in lambs and increasing mortality rate [174].

\subsection{Aquaculture}

Microalgae are vital for the artificial reproduction of several aquaculture species, especially molluscs [138]. Microalgae also play an important role in aquaculture, other than as a food source for zooplanktons by stabilising $\mathrm{pH}$, reducing bacterial growth, and improving the quality of rearing medium [175]. This leads to improved survival and growth compared to that of clear water fed with artificial diets [176]. Microalgae are the natural base of the entire aquatic food chain. This has led to their widespread incorporation as an important food source and feed additive in the commercial rearing of many aquatic animals, including molluscs, shrimp, and rotifers [177]. Filtering molluscs are by far the greatest consumer of microalgae in aquaculture, with $10.1 \times 10^{6}$ tonnes produced in 1999, compared to shrimp (1.2 $\times 10^{6}$ tonnes), and small larvae fish, such as sea breams and flatfish (177,400 tonnes) [178].

Replacements of live microalgae are already commercially available (such as Chaetoceros 1000 "Premium Fresh" Instant Algae ${ }^{\mathrm{TM}}$ paste, Liqualife ${ }^{\mathrm{TM}}$ liquid larval feed, Zeigler ${ }^{\mathrm{TM}}$ E-Z Larvae liquid feed, and Zeigler ${ }^{\mathrm{TM}}$ Z-Plus feed), but typically provide inferior growth and survival rates [179]. For example, the survival rate of brown larval shrimp (Farfantepenaeus aztecus) significantly decreased from $90.86 \pm 3.19 \%$ when fed live microalgae, to $14.865 \pm 14.35 \%$ in shrimp fed with $100 \%$ replacement E-Z larvae [179].

Microalgae are also often used as a dietary supplement to refine the products of aquaculture and increase their valorisation. Carotenoid pigments, such as astaxanthin derived from Haematococcus pluvalis, are incorporated into the diets of salmonoids, shrimp, lobsters, and crayfish, to give them their characteristic pink flesh [180]. Similarly, inclusion of astaxanthin at a concentration of $30 \mathrm{ppm}$ significantly increases the colour pattern and intensity of ornamental fish, including tetras, cichlids, gouramis, damos, goldfish, and koi, increasing their market value several fold [147].

Red seaweed has been suggested as a promising protein source feed additive. Incorporating 10\% Gracilaria chilensis in the diet of Atlantic salmon (Salmo solar) was reported to significantly increase specific growth rate by $1.51 \% \pm 0.12 \%$ compared to the control diet [181]. Including $1.0 \%$ and $10 \%$ G. chilensis in the diets of $S$. solar was also suggested to increase antiviral activity against the infectious salmon anaemia (ISA) virus. Similarly, inclusion of $5 \%$ and $15 \%$ P. palmata was reported to improve 
hepatic function and have a positive effect on body lipid content in S. salar compared to the control diets [182]. Wild abalone are opportunistic feeders that consume a variety of macroalgae species and typically have increased growth rate in captivity when fed a diet with several species compared to single species diets [183]. Haliotis tuberculata coccinea fed with a mixed diet including Ulva rigida, Hypnea spinella, and Gracilaria cornea displayed significantly greater growth rates, length, and weight gain than diets consisting of single algal species [184]. Seaweed is also often used in the feed of sea cucumber culture systems, which are used for human consumption in many Asian countries. $L$. japonica and $U$. lactuca have been reported as an economical additive to the diets of sea cucumber Apostichopus japonicas with low ammonia-nitrogen production and suitable digestibility [185].

\subsection{Bioactive Peptides}

Bioactive peptides are particular amino acid sequences that can have additional physiological health benefits beyond their basic nutritional value [126]. These peptides are typically between 2 and 30 amino acids in length and have hormone-like properties. Bioactive peptides are inactive within the parent proteins, but can be released through fermentation or hydrolysis. Milk proteins remain the most common source for bioactive peptides [186,187]. However, bioactive peptides have also been identified in a number of food sources, including meat, egg, fish, and blood, as well as plant sources, including rice, soybean, wheat, pea, broccoli, garlic, and algae [132,188-197].

Bioactive peptides have been found to have a multitude of beneficial effects, including anti-hypertensive, anti-oxidative, antithrombotic, hypocholesterolemic, opioid, mineral binding, appetite suppression, anti-microbial, immunomodulatory, and cytomodulatory properties [187]. Bioactive peptides from algae have also been found to display bioactive properties, although they are not as well characterised compared to peptides from other sources (Table 2) [198]. Antimicrobial peptides have been identified from Saccharina longicruris protein hydrolysates, significantly decreasing the growth rate of Staphylococcus aureus [199]. The hexapeptide Glu-Asp-Arg-Leu-Lys-Pro isolated from Ulva sp. was demonstrated to have mitogenic activity in skin fibroblasts [200].

Table 2. Angiotensin-I-converting enzyme (ACE)-I inhibitory bioactive peptides derived from seaweed and microalgae. The potency of the peptides is indicated by their $\mathrm{IC}_{50}$ values, which refers to the concentration required to inhibit enzyme activity by $50 \%$.

\begin{tabular}{|c|c|c|c|c|}
\hline Source & Hydrolytic Method & Peptide Sequence & $\mathrm{IC}_{50}$ & Reference \\
\hline $\begin{array}{l}\text { Undaria pinnatifida } \\
\text { (wakame) }\end{array}$ & Pepsin & $\begin{array}{l}\text { Ala-Ile-Tyr-Lys } \\
\text { Tyr-Lys-Tyr-Tyr } \\
\text { Lys-Phe-Tyr-Gly } \\
\text { Tyr-Asn-Lys-Leu }\end{array}$ & $\begin{array}{l}213 \mu \mathrm{M} \\
64.2 \mu \mathrm{M} \\
90.5 \mu \mathrm{M} \\
90.5 \mu \mathrm{M}\end{array}$ & [201] \\
\hline $\begin{array}{l}\text { Undaria pinnatifida } \\
\text { (wakame) }\end{array}$ & Hot water extraction & $\begin{array}{l}\text { Tyr-His } \\
\text { Lys-Trp } \\
\text { Lys-Tyr } \\
\text { Lys-Phe } \\
\text { Phe-Tyr } \\
\text { Val-Trp } \\
\text { Val-Phe } \\
\text { Ile-Tyr } \\
\text { Ile-Trp } \\
\text { Val-Tyr }\end{array}$ & $\begin{array}{c}5.1 \mu \mathrm{M} \\
10.8 \mu \mathrm{M} \\
7.7 \mu \mathrm{M} \\
28.3 \mu \mathrm{M} \\
3.7 \mu \mathrm{M} \\
10.8 \mu \mathrm{M} \\
43.7 \mu \mathrm{M} \\
2.7 \mu \mathrm{M} \\
12.4 \mu \mathrm{M} \\
11.3 \mu \mathrm{M}\end{array}$ & [202] \\
\hline Ecklonia cava & $\begin{array}{c}\text { Alcalase } \\
\text { Flavourzyme } \\
\text { Kojizyme } \\
\text { Neutrase } \\
\text { Protamex }\end{array}$ & $\begin{array}{l}\text { Enzymatic digest } \\
\text { Enzymatic digest } \\
\text { Enzymatic digest } \\
\text { Enzymatic digest } \\
\text { Enzymatic digest }\end{array}$ & $\begin{array}{l}2.79 \mu \mathrm{g} / \mathrm{mL} \\
3.56 \mu \mathrm{g} / \mathrm{mL} \\
2.33 \mu \mathrm{g} / \mathrm{mL} \\
3.10 \mu \mathrm{g} / \mathrm{mL} \\
3.28 \mu \mathrm{g} / \mathrm{mL}\end{array}$ & [204] \\
\hline
\end{tabular}


Table 2. Cont.

\begin{tabular}{|c|c|c|c|c|}
\hline Source & Hydrolytic Method & Peptide Sequence & $\mathrm{IC}_{50}$ & Reference \\
\hline \multirow{4}{*}{ Porphyra yezoensis } & & Ile-Tyr & $2.69 \mu \mathrm{M}$ & \multirow{4}{*}{ [205] } \\
\hline & & Met-Lys-Tyr & $7.26 \mu \mathrm{M}$ & \\
\hline & & Ala-Lys-Tyr-Ser-Tyr & $1.52 \mu \mathrm{M}$ & \\
\hline & & Leu-Arg-Tyr & $5.06 \mu \mathrm{M}$ & \\
\hline \multirow{3}{*}{ Hizikia fusiformis } & & Gly-Lys-Tyr & $3.92 \mu \mathrm{M}$ & \multirow{3}{*}{ [206] } \\
\hline & & Ser-Val-Tyr & $8.12 \mu \mathrm{M}$ & \\
\hline & & Ser-Lys-Thr-Tyr & $11.07 \mu \mathrm{M}$ & \\
\hline \multirow{4}{*}{ Palmaria palmata (dulse) } & \multirow{4}{*}{ Thermolysin } & Val-Tyr-Arg-Thr & $0.14 \mu \mathrm{M}$ & \multirow{4}{*}{ [207] } \\
\hline & & Leu-Asp-Tyr & $6.1 \mu \mathrm{M}$ & \\
\hline & & Leu-Arg-Tyr & $0.044 \mu \mathrm{M}$ & \\
\hline & & Phe-Glu-Gln-Trp-Ala-Ser & $2.8 \mu \mathrm{M}$ & \\
\hline \multirow{6}{*}{ Chlorella vulgaris } & \multirow{10}{*}{ Pepsin } & Ile-Val-Val-Glu & $315.3 \mu \mathrm{M}$ & \multirow{10}{*}{ [208] } \\
\hline & & Ala-Phe-Leu & $63.8 \mu \mathrm{M}$ & \\
\hline & & Phe-Ala-Leu & $26.3 \mu \mathrm{M}$ & \\
\hline & & Ala-Glu-Leu & $57.1 \mu \mathrm{M}$ & \\
\hline & & Val-Val-Pro-Pro-Ala & $79.5 \mu \mathrm{M}$ & \\
\hline & & Ile-Ala-Glu & $34.7 \mu \mathrm{M}$ & \\
\hline \multirow{4}{*}{ Arthrospira platensis } & & Phe-Ala-Leu & $11.4 \mu \mathrm{M}$ & \\
\hline & & Ala-Glu-Leu & $11.4 \mu \mathrm{M}$ & \\
\hline & & Ile-Ala-Pro-Gly & $11.4 \mu \mathrm{M}$ & \\
\hline & & Val-Ala-Phe & $35.8 \mu \mathrm{M}$ & \\
\hline Nannochloropsis oculata & Alcalase & Leu-Val-Thr-Val-Met & $18.0 \mu \mathrm{M}$ & [209] \\
\hline \multirow[t]{2}{*}{ Nannochloropsis oculata } & \multirow[t]{2}{*}{ Pepsin } & Gly-Met-Asn-Asn-Leu-Thr-Pro & $123 \mu \mathrm{M}$ & \multirow{2}{*}{ [210] } \\
\hline & & Leu-Glu-Gln & $173 \mu \mathrm{M}$ & \\
\hline Chlorella ellipsoidea & $\begin{array}{c}\text { Protamex, Kojizyme, Neutrase, } \\
\text { Flavourzyme, Alcalase, trypsin, } \\
\alpha \text {-chymotrypsin, pepsin, and papain }\end{array}$ & Val-Glu-Gly-Tyr & $128.4 \mu \mathrm{M}$ & [211] \\
\hline Chlorella vulgaris & Flavourzyme, alcalase, papain, and pepsin & $\begin{array}{l}\text { Val-Glu-Cys-Tyr-Gly-Pro-Asn } \\
\text {-Arg-Pro-Gln-Phe }\end{array}$ & $29.6 \mu \mathrm{M}$ & [212] \\
\hline
\end{tabular}

Owing to the high levels of oxidative stresses and free radicals in their environment, microalgae and seaweed have developed many defensive systems that can stimulate antioxidant activity when consumed [213]. Antioxidant peptides have therefore been isolated from several species of microalgae, including C. vulgaris, Navicula incerta, and Chlorella ellipsoidea [214-217]. Antioxidant peptides have also been isolated from various Irish and Korean brown seaweeds, which indicated that those with higher phenolic content, such as Ecklonia cava and Sargassum coreanum, correlated with increased antioxidant activity [218-220]. Peptides displaying antioxidant and anticancer bioactivity have also been reported in Sri Lankan red and green seaweed, of which Caulerpa racemosa demonstrated the most promising free radical scavenging and anticancer bioactivity [221].

Microalgae have also been reported to display anticancer peptides, such as Chlorella pyrenoidosa antitumor polypeptide (CPAP) derived from Chlorella pyrenoidosa and polypeptide $\mathrm{Y} 2$ derived from A. platensis $[222,223]$. Protein hydrolysates from Porphyra columbina phycocolloid extraction by-products were reported to have immunosuppressive, anti-hypertensive, and antioxidant capacities [224]. Anti-inflammatory peptides have been isolated from microalgae, such as Chlorella 11-peptide derived from C. pyrenoidosa [225], as well as peptides derived from A. maxima (Leu-Asp-Ala-Val-Asn-Arg and Met-Met-Leu-Asn-Phe), which were additionally reported to display anti-atherosclerosis bioactivity [226,227]. Similarly, anti-atherosclerosis peptides have also been isolated from P. palmata and were shown to be non-toxic in Zebrafish at a concentration of $1 \mathrm{mg} / \mathrm{mL}$ [228].

Algal peptides have been reported to display several other bioactivities, including hepatoprotective, immunomodulatory, ultraviolet (UV) radiation-protective, anti-osteoporosis, and anti-coagulant [229-234]. Finally, it is important to note that several studies have reported that short algae-derived peptides are capable of resisting gastrointestinal digestion from enzymes such as trypsin, pepsin, and chymotrypsin $[203,207,235]$. This is an essential trait for bioactive peptides in order to achieve their physiological effect at their site of action [236]. 


\section{Anti-Hypertensive Peptides}

Hypertension is the single largest risk factor attributed to deaths worldwide, making it an ideal target for bioactive peptides [237]. Angiotensin-I-converting enzyme (ACE-I) is a proteolytic enzyme that affects vasoconstriction in two major blood pressure regulatory systems, namely renin-angiotensin-aldosterone system (RAAS) and kinin-kallikrein system, leading on to the development of hypertension (Figure 2) [126]. ACE-I inhibitors have therefore become one of the most commonly studied targets, and with global annual sales exceeding US \$6 billion, ACE-I inhibitory drugs can be considered as one of the major protease inhibitor success stories [238]. Synthetic ACE-I inhibitor drugs, such as captopril, enalapril, and alacepril, often come with several side effects, including hypotension, dry cough, and impaired renal function [19]. Function foods with anti-hypertensive bioactivities have therefore become a popular alternative to synthetic drugs, especially for individuals who are borderline hypertensive and do not warrant the prescription of pharmaceutical drugs [239].

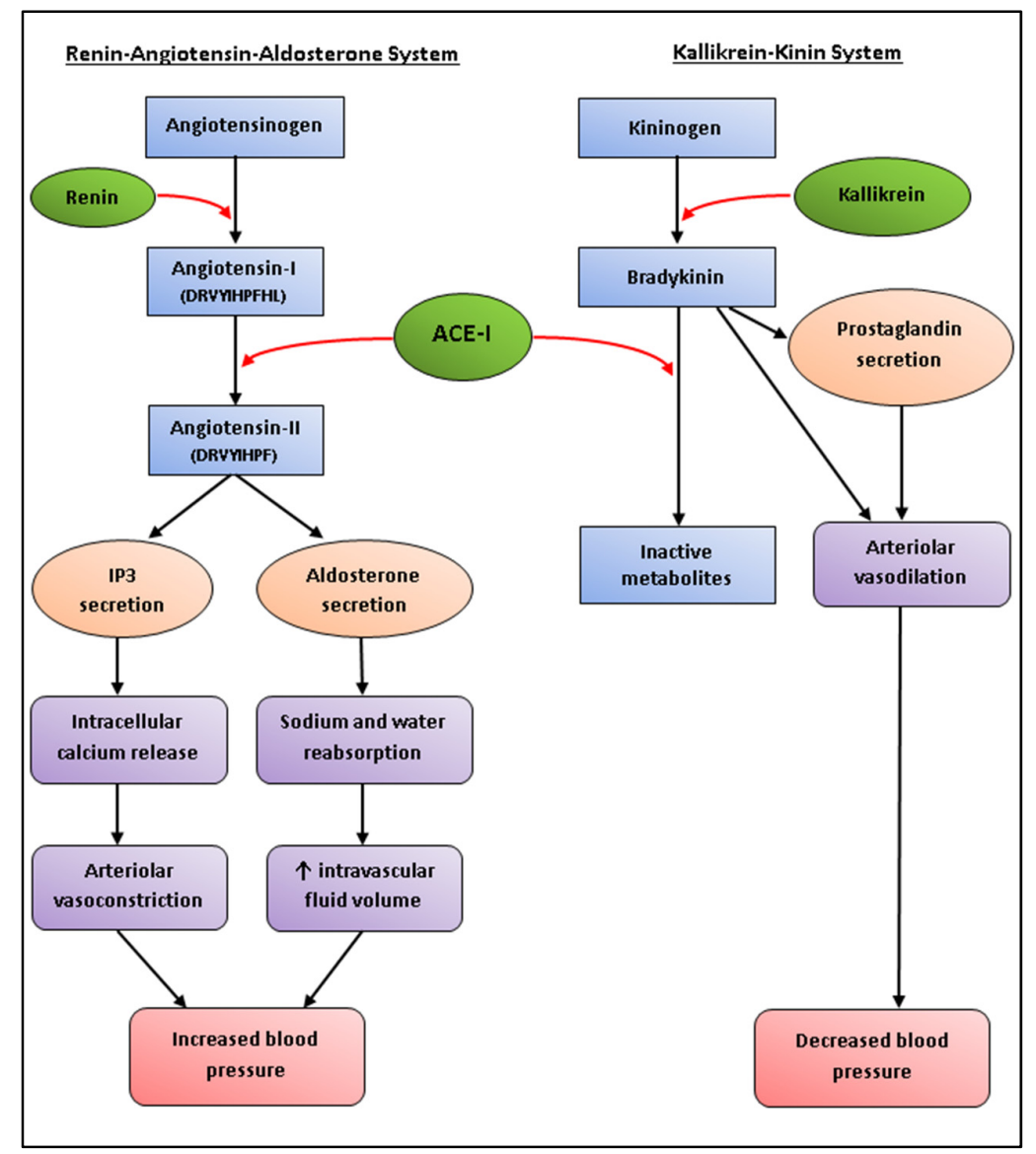

Figure 2. Schematic representation of the renin-angiotensin-aldosterone system (RAAS) and the hypertensive effect of angiotensin-I-converting enzyme (ACE-I). Angiotensinogen is converted to the decapeptide angiotensin-I by renin. ACE-I cleaves the C-terminal dipeptide His-Leu of angiotensin-I to form angiotensin-II. Binding of angiotensin-II to its receptor (AT1) stimulates the secretion of inositol 1,4,5-triphosphate (IP3) and aldosterone, which induce arteriolar vasoconstriction and increased intravascular fluid volume, respectively, resulting in increased blood pressure. Within the kallikrein-kinin system, kallikrein converts kininogen to bradykinin, which induces arteriolar vasodilation by prostaglandin secretion and binding of bradykinin with its receptor, resulting in decreased blood pressure. However, the hypotensive effect of bradykinin is largely dependent on the rate of degradation by ACE-I, which hydrolyzes bradykinin to form inactive metabolites. 
ACE-I-inhibitory peptides have been isolated from a variety of seaweed and microalgae sources [132]. Four tetrapeptides were identified from peptic digests of $U$. pinnatifida which displayed in vitro ACE-I inhibitory and in vivo anti-hypertensive bioactivity in spontaneously hypertensive rats (SHRs) (Table 2) [201]. Suetsuna and colleagues also identified several dipeptides from U. pinnatifida using hot water extraction [202]. Both single administration and repeated dose administration of four of the dipeptides significantly reduced blood pressure in SHRs. For example, a single administration of $50 \mathrm{mg} / \mathrm{kg}$ body weight Tyr-His, Phe-Tyr, and Ile-Tyr lowered systolic blood pressure (SBP) by 50, 46, and $33 \mathrm{~mm} \mathrm{Hg}$, respectively, after $3 \mathrm{~h}$ [202]. The dipeptide Lys-Tyr took slightly longer to have the greatest effect, with a reduction in SBP of $45 \mathrm{~mm} \mathrm{Hg}$ observed after $6 \mathrm{~h}$. Similarly, one week of continuous oral administration of $10 \mathrm{mg} / \mathrm{kg}$ body weight/day Tyr-His, Lys-Tyr, Phe-Tyr, and Ile-Tyr reduced SBP by 34, 26, 34 and $25 \mathrm{~mm} \mathrm{Hg}$, respectively [202]. Similarly, Sato and colleagues (2002) also identified ACE-I inhibitory peptides from $U$. pinnatifida which displayed in vitro and in vivo bioactivity [203].

Dipeptides were isolated from wakame Protease S "Amano" hydrolysates by three-step high-performance liquid chromatography. The peptides showed strong ACE-I inhibitory potency and four of the dipeptides (Val-Tyr, Ile-Tyr, Phe-Tyr, and Ile-Trp) were reported to significantly reduce blood pressure in SHRs comparable to that of the positive control (captopril) when administered at a dose of $1 \mathrm{mg} / \mathrm{kg}$ body weight (Table 2) [203]. Cha and colleagues (2006) reported promising peptides derived from digestion of $70{ }^{\circ} \mathrm{C}$ aqueous extracts of $E$. cava using five proteases from Novo Co. (Novozyme Nordisk, Bagsvaerd, Denmark), including alcalase, flavourzyme, kojizyme, neutrase, and protamex [204]. ACE-I inhibitory peptides have also been isolated from P. columbina, P. palmata, Bangia fusco-purpurea, P. yezoensis, and H. fusiformis (Table 2) [205-207,235,240].

In addition to seaweed, ACE-I inhibitory bioactive peptides have also been isolated from a number of microalgae species. Suetsuna and Chen (2001) identified several peptides from C. vulgaris and A. platensis which displayed promising ACE-I inhibitory and anti-hypertensive activity in SHRs (Table 2) [208]. Nannochloropsis oculata has been shown to be a promising source of commercially exploitable biodiesel due to its high lipid content (up to $28.7 \% \mathrm{dw}$ ) [209]. In order to maximise its potential, while minimising waste disposal costs, biodiesel by-products were analysed for ACE-I inhibitory peptides. The commercial enzymes Alcalase, Neutrase, Flavourzyme, Pancreatic Trypsin Novo (PTN), and Protamex were used to generate hydrolysates, of which the Alcalase-generated peptide Leu-Val-Thr-Val-Met was identified as the most potent [209]. In a similar study, N. oculata was also digested with a variety of proteases, including pepsin, trypsin, $\alpha$-chymotrypsin, papain, Alcalase, and Neutrase for the generation of ACE-I inhibitory hydrolysates [210]. The pepsin hydrolysates exhibited the highest ACE-I inhibitory bioactivity, of which two peptide sequences (Gly-Met-Asn-Asn-Leu-Thr-Pro and Leu-Glu-Gln) in particular were identified as having the greatest activity (Table 2). Hydrolysis of C. ellipsoidea using the proteases Protamax, Kojizyme, Neutrase, Flavourzyme, Alcalase, trypsin, $\alpha$-chemotrypsin, pepsin, and papain generated several ACE-I inhibitory peptides, of which Val-Glu-Gly-Tyr was shown to be the most potent in vitro ACE-I inhibitor and in vivo anti-hypertensive with SHRs (Table 2) [211].

An anti-hypertensive peptide (Ile-Arg-Leu-Ile-Ile-Val-Leu-Met-Pro-Ile-Leu-Met-Ala) has also been isolated from P. palmata, which was reported to inhibit renin at concentrations similar to that that of the positive control [241]. Renin catalyzes the initial rate-limiting step within the RAAS, and is therefore an important target for the treatment of high blood pressure (Figure 2) [242].

\section{Challenges}

\subsection{Access Rights}

At present, all seaweed species are harvested by hand in Ireland. This includes the most economically valuable species brown seaweed Ascophyllum nodosum and the red calcified coralline seaweeds Phymatolithon purpureum and Lithothamnion corallioides (commonly called maërl) [243]. 
The legislation for harvesting seaweed in Ireland is based on the Foreshore Acts 1933-1998, which states that the Department of Communications Marine and Natural Resources is empowered to grant licences for seaweed harvesting on the seabed out to 12 nautical miles [244]. There are currently no restrictions on harvesting quantities in Ireland, nor are there any restrictions on harvesting times. The only exception to this is for maërl due to its extremely slow growth rate (0.6-1.5 mm per annum) [245]. However, the future implementation of mechanical harvesting methods will likely require a review of existing legislation to ensure appropriate access rights and sustainable harvesting yields are maintained. Mechanical harvesting of Laminaria spp. is already present in various European countries, such as France and Norway, providing a valuable resource for making any such revisions [243].

\subsection{Variability}

An additional challenge, which is particularly relevant in the production of bioactive peptides, are the high levels of variability in algal proteins. The protein content can vary by season, temperature, and location in which the seaweed is harvested [46]. The relative composition of particular proteins within the plant can also differ, changing the concentrations of amino acids and therefore altering the yield of desired peptides as a consequence [246]. For example, annual monitoring of P. palmata harvested on the French Atlantic coast showed that protein levels were highest in the winter and spring months, varying from 9 to 25\%, and peaking in May [247]. Similarly, Gracilaria cervicornis and S. vulgare varied by season, with protein levels negatively correlating with temperature and salinity [248]. Different harvest locations of $U$. pinnatifida in New Zealand also significantly affected the protein content and amino acid composition [249].

\subsection{Scalability}

The scalability of protein extraction from algae is a further obstacle that needs to be overcome before seaweed and microalgae become a viable source. Algal protein extraction is still very much in its infancy, meaning that many of the methods that have been developed are still at small scale [132]. PEF and ultrasound have been suggested as being suitable for large scale algal protein extraction [250]. Membrane technologies may also be scalable for commercial applications, with ultrafiltration reported as being suitable for R-phycoerythrin extraction from the seaweed G. turuturu at the industrial scale [109].

\subsection{Digestibility}

One of the most important challenges for extracting proteins from algae is the high levels of cell wall anionic polysaccharides which can become bound to the proteins and create viscous medium, further increasing the difficulty of protein extraction [46]. The morphology of different seaweed species has been suggested to be an important factor in determining protein yield, with tougher thallus forms reported to require increased processing [68]. Several brown algae species (Eisena bicyclis, H. fusiformis, $U$. pinnatifida) were reported to have reduced in vitro digestibility $(51.8 \%-57.1 \%)$ compared to red algae P. palmata and P. tenera ( $70.2 \%$ and $87.3 \%$, respectively), which was suggested to have been due to increased levels of dietary fibre [34]. Furthermore, the type of polysaccharide has been shown to influence the level of protein digestion. P. palmata and G. verrucosa, both red seaweeds, were shown to have significantly different levels of in vitro corrected nitrogen digestibility $(1.9 \%$ and $16.3 \%$ after $6 \mathrm{~h}$, respectively) [251]. This was largely attributed to differences in polysaccharide fractions (pentoses and hexoses, respectively).

Treatments to disrupt the cellulosic cell wall could help to overcome this issue to make algal proteins and other cell components more accessible [28]. Heat treatment is one such option that can improve food taste, texture, safety in terms of allergenicity and microbial load, and preservation, while also increasing bioavailability and utilisation of proteins by partial denaturation and breakdown of proteins into peptides, allowing for easier access by proteolytic enzymes [252]. An example of this can be seen with boiling of P. palmata, resulting in a 64\%-96\% increase in liberated amino acids [253]. 
Alternatively, fermentation can also increase protein digestibility due to the degradation of insoluble fibres, such as xylan. This can be seen with the fermentation of $P$. palmata using the fungal mould Trichoderma pseudokoningii which was found to decrease the xylan content from 53\% to $19 \% \mathrm{dw}$ [75]. Washing in distilled water has also been shown to be a simple, yet effective method for improving in vitro digestibility by solubilising and removing mineral salts [75].

Alternatively, the method of drying seaweed has been shown to influence algal protein digestibility. Compared to freeze-drying, oven-drying was demonstrated to significantly improve $(p<0.05$, two-way ANOVA) the protein extractability and in vitro bioaccessibility of brown seaweed species Sargassum hemiphyllum, Sargassum henslowianum, and Sargassum patens [45]. The increased extractability from oven-drying were suggested to have been due to the decomposition of phenolic compounds at the high temperatures, as well as increased disruption of anionic or neutral polysaccharides found within the cell wall of the seaweed [45].

Protein digestibility can also be largely influenced by the presence of phenolic compounds present in algae, especially phlorotannins in brown seaweeds [45]. Oxidised phenolic compounds can react with amino acids to form insoluble complexes, which may inhibit proteolytic enzymes and thus decrease their nutritive values [65]. The negative correlation between phenolic content and digestibility was demonstrated by $U$. lactuca which was reported to have higher phenolic content $(38.8 \pm 0.5 \%)$ compared to the red algae H. charoides $(16.9 \% \pm 1.0 \%)$ and $H$. japonica $(16.3 \% \pm 0.03 \%)$ and thus, lower bioaccessibility $(85.7 \% \pm 1.9 \%, 88.7 \% \pm 0.7 \%$, and $88.9 \% \pm 1.4 \%$, respectively) [65]. This is likely to be a greater issue in brown algae, as these are typically higher in phenolics, including catechins, flavanols, and phlorotannins [10,67].

\subsection{Food Safety}

While algae can be natural accumulators of vitamins and minerals, they can also gather toxic elements, such as heavy metals. There are therefore strict legal limits in Europe for the safe maximum exposure of heavy metals, such as mercury, arsenic, lead, and cadmium, in foods for human consumption. These limits are based upon the recommendations of the Joint FAO/WHO Expert Committee on Food Additives (JECFA) and the Panel on Contaminants in the Food Chain of the European Food Safety Authority (CONTAM Panel), and are outlined in the legislation under Commission Regulation (EC) No. 1881/2006 [254].

The tolerable weekly intake (TWI) of methylmercury, arsenic, lead, and cadmium are 1.6, 15, 25, and $25 \mu \mathrm{g} / \mathrm{kg}$ body weight, respectively [255-258]. The CONTAM panel has reported that the current lead TWI ( $15 \mu \mathrm{g} / \mathrm{kg}$ body weight) may no longer be appropriate due to low levels found in foodstuffs, while arsenic TWI $(1.6 \mu \mathrm{g} / \mathrm{kg}$ body weight) should be lowered due to cancers and adverse effects observed at current legal limits $[256,257]$. Lead and mercury appear to occur in algae at levels that are safe for human consumption $[259,260]$. In contrast, arsenic and cadmium have been identified in algae at levels above the legal limits, with $H$. fusiformis in particular containing a high content of these toxic heavy metals $[259,260]$. Microalgae do not appear to exceed legal levels of heavy metals [261].

The lack of regulation for algae as a dietary supplement is of additional concern, leading to large variations between different batches from the same producer [262]. This has led to concerns being raised about quality and contamination at the production and processing stages [263]. Downstream applications for which the algal proteins are intended can play a role in determining processing methods. For example, food grade reagents and processes may be required for proteins intended for human consumption, whereas this may not be such an issue with proteins intended for commercial applications or animal feed [264]. Furthermore, any reagents used for the production or extraction of algal proteins must also be environmentally friendly with minimum impact on local ecosystems [265]. Following protein extraction, greater emphasis must additionally be placed on protein purification, with salt removal and buffer exchange being important steps [266]. Membrane technologies, such as ultrafiltration and nanofiltration, have already been implemented in this context within the dairy 
industry, although these technologies could also be used for other food applications, including algal proteins [267].

\subsection{Price}

A critical factor that will determine the commercial viability of microalgae and seaweed is their competitiveness compared to other sources on the market. For example, a major application for the production of microalgae is the extraction of lipids to be converted to biofuel. However, while they are a greener alternative for the environment, they are still not competitive compared to fossil-based petroleum fuels [266]. Algae competitiveness could be further increased by taking a holistic view and maximising the extraction of all available high-value components by cascading biorefinery. Conventional methods of algal protein extraction are often quite wasteful as they typically dispose of the algae by-products following processing [88]. Seaweed is ideally suited for cascading biorefinery because it contains many high-value components as well as bulky low-value components that are considered raw materials for the bio-based economy, such as xylose and glucose [268]. As several studies have shown, the by-products of algae can still have many applications that could be of economic value $[209,215,224]$. Further research is needed to develop new methods that will enable algal protein production, extraction and processing costs to be lowered.

\section{Discussions}

Seaweed and microalgae are generally considered to be a promising source of nutrition, rich in vitamins, minerals, and protein. Some species have even been reported to display protein at concentrations greater than traditional plant and animal protein sources [28]. Within these protein sequences, bioactive peptides have been identified with beneficial properties for human health, including antioxidant, anticancer, anti-hypertensive, immunosuppressive, anti-atherosclerosis, and hepatoprotective effects [198]. Algae have also been reported to contain high quality proteins in terms of EAA content [3], as well as displaying in vitro protein digestibility that is comparable to commonly consumed plants [67]. However, there are conflicting reports about the bioavailability of algal proteins when examined in vivo. Several studies have demonstrated that consumption of raw, unprocessed seaweed can result in reduced growth [43,44]. In contrast, other studies have reported opposite findings, with seaweed proteins suggested as being a beneficial dietary supplement for improved animal growth, meat quality, and valorisation $[155,161,162]$. Furthermore, microalgae have long been used as the basal diet in the rearing of animals in aquaculture, especially molluscs [138].

One of the major reasons for reduced protein digestibility was suggested to be due to the high fibre content that makes up the algal cell wall [46]. Algae typically contain high levels of polysaccharides, although this can vary significantly in seaweed $(4 \%-76 \% \mathrm{dw})$ and microalgae $(8 \%-64 \% \mathrm{dw})$ according to species and time of harvest $[22,28]$. Similarly, phenolic compounds can react with amino acids to form insoluble compounds [65]. Great emphasis has therefore been placed on researching methods for breaking down of the anionic cell wall in order to allow the release of the valuable intracellular contents [13].

Conventional protein extraction methods, such as enzymatic hydrolysis and physical processes, are laborious, time-consuming, and may require the use of solvents [13]. Novel protein extraction methods, such as UAE, PEF, and MAE, have thus been investigated as a means of overcoming these limitations. UAE is a cost-effective and low-solvent consumption method for extraction of high-value compounds. UAE is already widely used at commercial scale in food processing and could therefore also be implemented for the extraction of algal proteins [81]. PEF for the extraction of intracellular algal components is still in its infancy, having predominantly been used for lipid extraction [93]. Nevertheless, its lack of solvent consumption or heat gives it potential for the future extraction of algal proteins [100]. MAE has been poorly studied in algae, although the high temperature involved would likely make it unsuitable for extraction of proteins [81]. Alternatively, membrane filtration technologies, such as those used in the dairy industry, could also be considered a gentle method for 
protein enrichment when used in conjunction with cell disruption methods. MF has already been demonstrated for harvesting whole microalgal cells, while UF was reported for the extraction of algal polysaccharides [106,107]. However, there remains to be a distinct lack of studies investigating the use of membrane technologies in the enrichment of algal proteins.

In conclusion, algae have been reported as a valuable source of nutrition. However, there are inconclusive reports about the digestibility of algae and the bioavailability of the proteins within. More research is needed to investigate the bioavailability of algal proteins in vivo. Cell disruption techniques will likely play an essential role in the successful extraction and enrichment of algal protein ingredients at a commercial scale. The most promising methods that have been used in algae to date are UAE and PEF, both of which are non-thermal, require low solvent consumption, and have been implemented at commercial scale for the extraction of compounds in other food processes. Alternatively, membrane technologies are a method for isolating compounds which show great promise, but have yet to be investigated sufficiently in algae.

Acknowledgments: Stephen Bleakley is in receipt of a Teagasc Walsh Fellowship (Grant No. 2016073). This work forms part of the BioAlgae project funded by the Teagasc (Grant No. NFNY6889-142).

Conflicts of Interest: The authors declare no conflict of interest.

\section{Abbreviations}

$\begin{array}{ll}\text { EAA(s) } & \text { essential amino acid(s) } \\ \text { FAO } & \text { Food and Agriculture Organisation of the United Nations } \\ \text { TNOASR } & \text { The Netherland Organisation for applied scientific research } \\ \text { TIM } & \text { TNOASR's Intestinal Model } \\ \text { UAE } & \text { ultrasound-assisted extraction } \\ \text { PEF } & \text { pulsed electric field } \\ \text { MAE } & \text { microwave-assisted extraction } \\ \text { MF } & \text { microfiltration } \\ \text { UF } & \text { ultrafiltration } \\ \text { WHO } & \text { World Health Organisation } \\ \text { ACE-I } & \text { angiotensin-I-converting enzyme } \\ \text { RAAS } & \text { renin-angiotensin-aldosterone system } \\ \text { SHR(s) } & \text { spontaneously hypertensive rat(s) } \\ \text { SBP } & \text { systolic blood pressure }\end{array}$

\section{References}

1. Godfray, H.C.J.; Beddington, J.R.; Crute, I.R.; Haddad, L.; Lawrence, D.; Muir, J.F.; Pretty, J.; Robinson, S.; Thomas, S.M.; Toulmin, C. Food security: The challenge of feeding 9 billion people. Science 2010, 327, 812-818. [CrossRef] [PubMed]

2. Tilman, D.; Balzer, C.; Hill, J.; Befort, B.L. Global food demand and the sustainable intensification of agriculture. Proc. Natl. Acad. Sci. USA 2011, 108, 20260-20264. [CrossRef] [PubMed]

3. Fleurence, J. Seaweed proteins: Biochemical, nutritional aspects and potential uses. Trends Food Sci. Technol. 1999, 10, 25-28. [CrossRef]

4. Gouveia, L.; Batista, A.P.; Sousa, I.; Raymundo, A.; Bandarra, N. Microalgae in Novel Food Products. In Food Chemistry Research Development; Konstantinos, N., Papadopoulos, P.P., Eds.; Nova Science Publishers: New York, NY, USA, 2008; pp. 75-112.

5. Van Krimpen, M.; Bikker, P.; Van der Meer, I.; Van der Peet-Schwering, C.; Vereijken, J. Cultivation, Processing and Nutritional Aspects for Pigs and Poultry of European Protein Sources as Alternatives for Imported Soybean Products; Wageningen UR Livestock Research: Lelystad, The Netherlands, 2013; p. 48.

6. Wallace, J. Increasing agricultural water use efficiency to meet future food production. Agric. Ecosyst. Environ. 2000, 82, 105-119. [CrossRef]

7. Pimentel, D.; Pimentel, M. Sustainability of meat-based and plant-based diets and the environment. Am. J. Clin. Nutr. 2003, 78, 660S-663S. [PubMed] 
8. Sampath-Wiley, P.; Neefus, C.D.; Jahnke, L.S. Seasonal effects of sun exposure and emersion on intertidal seaweed physiology: Fluctuations in antioxidant contents, photosynthetic pigments and photosynthetic efficiency in the red alga Porphyra umbilicalis kützing (Rhodophyta, Bangiales). J. Exp. Mar. Biol. Ecol. 2008, 361, 83-91. [CrossRef]

9. Pulz, O.; Gross, W. Valuable products from biotechnology of microalgae. Appl. Microbiol. Biotechnol. 2004, 65, 635-648. [CrossRef] [PubMed]

10. Wang, T.; Jonsdottir, R.; Ólafsdóttir, G. Total phenolic compounds, radical scavenging and metal chelation of extracts from icelandic seaweeds. Food Chem. 2009, 116, 240-248. [CrossRef]

11. Wijffels, R.H.; Barbosa, M.J. An outlook on microalgal biofuels. Science 2010, 329, 796-799. [CrossRef] [PubMed]

12. Cavalier-Smith, T. Evolution and relationships. In Unravelling the Algae: The Past, Present, and Future of Algal Systematics; Brodie, J., Ed.; CRC Press: Boca Raton, FL, USA, 2007; p. 21.

13. Kadam, S.U.; Tiwari, B.K.; O'Donnell, C.P. Application of novel extraction technologies for bioactives from marine algae. J. Agric. Food Chem. 2013, 61, 4667-4675. [CrossRef] [PubMed]

14. Food and Agriculture Organization. Food Balance Sheets; Food and Agriculture Organisation of the United Nations: Rome, Italy, 2013.

15. Food and Agriculture Organization. The State of World Fisheries and Aquaculture: Opportunties and Challenges; Food and Agriculture Organisation of the United Nations: Rome, Italy, 2014.

16. Cock, J.M.; Sterck, L.; Rouzé, P.; Scornet, D.; Allen, A.E.; Amoutzias, G.; Anthouard, V.; Artiguenave, F.; Aury, J.-M.; Badger, J.H. The ectocarpus genome and the independent evolution of multicellularity in brown algae. Nature 2010, 465, 617-621. [CrossRef] [PubMed]

17. Hoek, C.; Mann, D.; Jahns, H.M. Algae: An Introduction to Phycology; Cambridge University Press: Cambridge, UK, 1995.

18. Foster, M.S.; Schiel, D.R. Ecology of Giant Kelp Forests in California: A Community Profile; San Jose State University, Moss Landing Marine Labs.: Moss Landing, CA, USA, 1985.

19. Fitzgerald, C.; Gallagher, E.; Tasdemir, D.; Hayes, M. Heart health peptides from macroalgae and their potential use in functional foods. J. Agric. Food Chem. 2011, 59, 6829-6836. [CrossRef] [PubMed]

20. Karol, K.G.; McCourt, R.M.; Cimino, M.T.; Delwiche, C.F. The closest living relatives of land plants. Science 2001, 294, 2351-2353. [CrossRef] [PubMed]

21. McCourt, R.M.; Delwiche, C.F.; Karol, K.G. Charophyte algae and land plant origins. Trends Ecol. Evol. 2004, 19, 661-666. [CrossRef] [PubMed]

22. Holdt, S.L.; Kraan, S. Bioactive compounds in seaweed: Functional food applications and legislation. J. Appl. Phycol. 2011, 23, 543-597. [CrossRef]

23. Mouritsen, O.G.; Dawczynski, C.; Duelund, L.; Jahreis, G.; Vetter, W.; Schröder, M. On the human consumption of the red seaweed dulse (Palmaria palmata (L.) weber \& amp; mohr). J. Appl. Phycol. 2013, 25, 1777-1791.

24. Norton, T.A.; Melkonian, M.; Andersen, R.A. Algal biodiversity. Phycologia 1996, 35, 308-326. [CrossRef]

25. Chacón-Lee, T.; González-Mariño, G. Microalgae for "healthy" foods-Possibilities and challenges. Compr. Rev. Food Sci. Food Saf. 2010, 9, 655-675. [CrossRef]

26. Brennan, L.; Owende, P. Biofuels from microalgae-A review of technologies for production, processing, and extractions of biofuels and co-products. Renew. Sustain. Energy Rev. 2010, 14, 557-577. [CrossRef]

27. Capelli, B.; Cysewski, G.R. Potential health benefits of Spirulina microalgae. Nutrafoods 2010, 9, 19-26. [CrossRef]

28. Becker, E. Micro-algae as a source of protein. Biotechnol. Adv. 2007, 25, 207-210. [CrossRef] [PubMed]

29. Rodriguez-Garcia, I.; Guil-Guerrero, J.L. Evaluation of the antioxidant activity of three microalgal species for use as dietary supplements and in the preservation of foods. Food Chem. 2008, 108, 1023-1026. [CrossRef] [PubMed]

30. Boisen, S.; Eggum, B. Critical evaluation of in vitro methods for estimating digestibility in simple-stomach animals. Nutr. Res. Rev. 1991, 4, 141-162. [CrossRef] [PubMed]

31. Young, V.R.; Pellett, P.L. Plant proteins in relation to human protein and amino acid nutrition. Am. J. Clin. Nutr. 1994, 59, 1203S-1212S. [PubMed]

32. Hoffman, J.R.; Falvo, M.J. Protein-which is best. J. Sports Sci. Med. 2004, 3, 118-130. [PubMed] 
33. Food and Agriculture Organization; World Health Organization. Protein Quality Evaluation-Report of Joint FAO/WHO Expert Consultation; FAO: Rome, Italy, 1991.

34. Mišurcová, L.; Kráčmar, S.; Klejdus, B.; Vacek, J. Nitrogen content, dietary fiber, and digestibility in algal food products. Czech J. Food Sci. 2010, 28, 27-35.

35. Dawczynski, C.; Schubert, R.; Jahreis, G. Amino acids, fatty acids, and dietary fibre in edible seaweed products. Food Chem. 2007, 103, 891-899. [CrossRef]

36. Kolb, N.; Vallorani, L.; Stocchi, V. Chemical composition and evaluation of protein quality by amino acid score method of edible brown marine algae Arame (Eisenia bicyclis) and Hijiki (Hijikia fusiforme). Acta Aliment. 1999, 28, 213-222. [CrossRef]

37. Volkmann, H.; Imianovsky, U.; Oliveira, J.L.; Sant'Anna, E.S. Cultivation of arthrospira (Spirulina) platensis in desalinator wastewater and salinated synthetic medium: Protein content and amino-acid profile. Braz. J. Microbiol. 2008, 39, 98-101. [CrossRef] [PubMed]

38. Mišurcová, L.; Buňka, F.; Ambrožová, J.V.; Machů, L.; Samek, D.; Kráčmar, S. Amino acid composition of algal products and its contribution to RDI. Food Chem. 2014, 151, 120-125. [CrossRef] [PubMed]

39. Kakinuma, M.; Park, C.S.; Amano, H. Distribution of free L-cysteine and glutathione in seaweeds. Fish. Sci. 2001, 67, 194-196. [CrossRef]

40. MacArtain, P.; Gill, C.I.; Brooks, M.; Campbell, R.; Rowland, I.R. Nutritional value of edible seaweeds. Nutr. Rev. 2007, 65, 535-543. [CrossRef] [PubMed]

41. Guerra, A.; Etienne-Mesmin, L.; Livrelli, V.; Denis, S.; Blanquet-Diot, S.; Alric, M. Relevance and challenges in modeling human gastric and small intestinal digestion. Trends Biotechnol. 2012, 30, 591-600. [CrossRef] [PubMed]

42. Ekmekcioglu, C. A physiological approach for preparing and conducting intestinal bioavailability studies using experimental systems. Food Chem. 2002, 76, 225-230. [CrossRef]

43. Urbano, M.G.; Goñi, I. Bioavailability of nutrients in rats fed on edible seaweeds, nori (Porphyra tenera) and wakame (Undaria pinnatifida), as a source of dietary fibre. Food Chem. 2002, 76, 281-286. [CrossRef]

44. Suzuki, T.; Nakai, K.; Yoshie, Y.; Shirai, T.; Hirano, T. Digestibility of dietary fiber in brown Alga, Kombu, by rats. Bull. Jpn. Soc. Sci. Fish 1993, 59, 879-884. [CrossRef]

45. Wong, K.; Cheung, P.C. Influence of drying treatment on three Sargassum species. J. Appl. Phycol. 2001, 13, 43-50. [CrossRef]

46. Joubert, Y.; Fleurence, J. Simultaneous extraction of proteins and DNA by an enzymatic treatment of the cell wall of Palmaria palmata (Rhodophyta). J. Appl. Phycol. 2008, 20, 55-61. [CrossRef]

47. Carbonell-Capella, J.M.; Buniowska, M.; Barba, F.J.; Esteve, M.J.; Frígola, A. Analytical methods for determining bioavailability and bioaccessibility of bioactive compounds from fruits and vegetables: A review. Compr. Rev. Food Sci. Food Saf. 2014, 13, 155-171. [CrossRef]

48. Etcheverry, P.; Grusak, M.A.; Fleige, L.E. Application of in vitro bioaccessibility and bioavailability methods for calcium, carotenoids, folate, iron, magnesium, polyphenols, zinc, and vitamins B6, B12, D, and E. Front. Physiol. 2012, 3, 317. [CrossRef] [PubMed]

49. Alegría, A.; Garcia-Llatas, G.; Cilla, A. Static digestion models: General introduction. In The Impact of Food Bioactives on Health; Springer: Heidelberg, Germany, 2015; pp. 3-12.

50. Fernández-García, E.; Carvajal-Lérida, I.; Pérez-Gálvez, A. In vitro bioaccessibility assessment as a prediction tool of nutritional efficiency. Nutr. Res. 2009, 29, 751-760. [CrossRef] [PubMed]

51. Butts, C.A.; Monro, J.A.; Moughan, P.J. In vitro determination of dietary protein and amino acid digestibility for humans. Br. J. Nutr. 2012, 108, S282. [CrossRef] [PubMed]

52. Hur, S.J.; Lim, B.O.; Decker, E.A.; McClements, D.J. In vitro human digestion models for food applications. Food Chem. 2011, 125, 1-12. [CrossRef]

53. Minekus, M.; Marteau, P.; Havenaar, R. Multicompartmental dynamic computer-controlled model simulating the stomach and small intestine. Altern. Lab. Anim. ATLA 1995, 23, 197-209.

54. Minekus, M.; Smeets-Peeters, M.; Bernalier, A.; Marol-Bonnin, S.; Havenaar, R.; Marteau, P.; Alric, M.; Fonty, G. A computer-controlled system to simulate conditions of the large intestine with peristaltic mixing, water absorption and absorption of fermentation products. Appl. Microbiol. Biotechnol. 1999, 53, 108-114. [CrossRef] [PubMed] 
55. Barmpalia-Davis, I.M.; Geornaras, I.; Kendall, P.A.; Sofos, J.N. Differences in survival among 13 listeria monocytogenes strains in a dynamic model of the stomach and small intestine. Appl. Environ. Microbiol. 2008, 74, 5563-5567. [CrossRef] [PubMed]

56. Van den Abbeele, P.; Grootaert, C.; Marzorati, M.; Possemiers, S.; Verstraete, W.; Gérard, P.; Rabot, S.; Bruneau, A.; El Aidy, S.; Derrien, M. Microbial community development in a dynamic gut model is reproducible, colon region specific, and selective for Bacteroidetes and Clostridium cluster IX. Appl. Environ. Microbiol. 2010, 76, 5237-5246. [CrossRef] [PubMed]

57. Vardakou, M.; Mercuri, A.; Naylor, T.; Rizzo, D.; Butler, J.; Connolly, P.; Wickham, M.; Faulks, R. Predicting the human in vivo performance of different oral capsule shell types using a novel in vitro dynamic gastric model. Int. J. Pharm. 2011, 419, 192-199. [CrossRef] [PubMed]

58. Curto, A.L.; Pitino, I.; Mandalari, G.; Dainty, J.R.; Faulks, R.M.; Wickham, M.S.J. Survival of probiotic lactobacilli in the upper gastrointestinal tract using an in vitro gastric model of digestion. Food Microbiol. 2011, 28, 1359-1366. [CrossRef] [PubMed]

59. Dupont, D.; Bordoni, A.; Brodkorb, A.; Capozzi, F.; Cirkovic Velickovic, T.; Corredig, M.; Cotter, P.D.; de Noni, I.; Gaudichon, C.; Golding, M. An international network for improving health properties of food by sharing our knowledge on the digestive process. Food Dig. 2011, 2, 23-25. [CrossRef]

60. Minekus, M.; Alminger, M.; Alvito, P.; Ballance, S.; Bohn, T.; Bourlieu, C.; Carriere, F.; Boutrou, R.; Corredig, M.; Dupont, D. A standardised static in vitro digestion method suitable for food-An international consensus. Food Funct. 2014, 5, 1113-1124. [CrossRef] [PubMed]

61. Egger, L.; Menard, O.; Delgado-Andrade, C.; Alvito, P.; Assunção, R.; Balance, S.; Barberá, R.; Brodkorb, A.; Cattenoz, T.; Clemente, A.; et al. The harmonized infogest in vitro digestion method: From knowledge to action. Food Res. Int. 2016, 88, 217-225. [CrossRef]

62. Glahn, R.P.; Lee, O.A.; Yeung, A.; Goldman, M.I.; Miller, D.D. Caco-2 cell ferritin formation predicts nonradiolabeled food iron availability in an in vitro digestion/Caco-2 cell culture model. J. Nutr. 1998, 128, 1555-1561. [PubMed]

63. Rousset, M. The human colon carcinoma cell lines HT-29 and Caco-2: Two in vitro models for the study of intestinal differentiation. Biochimie 1986, 68, 1035-1040. [CrossRef]

64. Mahler, G.J.; Shuler, M.L.; Glahn, R.P. Characterization of Caco-2 and HT29-MTX cocultures in an in vitro digestion/cell culture model used to predict iron bioavailability. J. Nutr. Biochem. 2009, 20, 494-502. [CrossRef] [PubMed]

65. Wong, K.; Cheung, P.C. Nutritional evaluation of some subtropical red and green seaweeds part II. In vitro protein digestibility and amino acid profiles of protein concentrates. Food Chem. 2001, 72, 11-17. [CrossRef]

66. Bikker, P.; Krimpen, M.M.; Wikselaar, P.; Houweling-Tan, B.; Scaccia, N.; Hal, J.W.; Huijgen, W.J.; Cone, J.W.; López-Contreras, A.M. Biorefinery of the green seaweed Ulva lactuca to produce animal feed, chemicals and biofuels. J. Appl. Phycol. 2016, 28, 3511-3525. [CrossRef] [PubMed]

67. Tibbetts, S.M.; Milley, J.E.; Lall, S.P. Nutritional quality of some wild and cultivated seaweeds: Nutrient composition, total phenolic content and in vitro digestibility. J. Appl. Phycol. 2016, 28, 3575-3585. [CrossRef]

68. Barbarino, E.; Lourenço, S.O. An evaluation of methods for extraction and quantification of protein from marine macro-and microalgae. J. Appl. Phycol. 2005, 17, 447-460. [CrossRef]

69. Kadam, S.U.; Álvarez, C.; Tiwari, B.K.; O’Donnell, C.P. Extraction and characterization of protein from irish brown seaweed ascophyllum nodosum. Food Res. Int. 2016. [CrossRef]

70. Fleurence, J.; Le Coeur, C.; Mabeau, S.; Maurice, M.; Landrein, A. Comparison of different extractive procedures for proteins from the edible seaweeds Ulva rigida and Ulva rotundata. J. Appl. Phycol. 1995, 7, 577-582. [CrossRef]

71. Jordan, P.; Vilter, H. Extraction of proteins from material rich in anionic mucilages: Partition and fractionation of vanadate-dependent bromoperoxidases from the brown algae Laminaria digitata and L. Saccharina in aqueous polymer two-phase systems. Biochim. Biophys. Acta (BBA) Gen. Subj. 1991, 1073, 98-106. [CrossRef]

72. Fleurence, J. The enzymatic degradation of algal cell walls: A useful approach for improving protein accessibility? J. Appl. Phycol. 1999, 11, 313-314. [CrossRef]

73. Harnedy, P.A.; FitzGerald, R.J. Extraction of protein from the macroalga Palmaria palmata. LWT Food Sci. Technol. 2013, 51, 375-382. [CrossRef] 
74. Fleurence, J.; Massiani, L.; Guyader, O.; Mabeau, S. Use of enzymatic cell wall degradation for improvement of protein extraction from chondrus crispus, gracilaria verrucosa and Palmaria palmata. J. Appl. Phycol. 1995, 7, 393-397. [CrossRef]

75. Marrion, O.; Schwertz, A.; Fleurence, J.; Gueant, J.L.; Villaume, C. Improvement of the digestibility of the proteins of the red alga Palmaria palmata by physical processes and fermentation. Mol. Nutr. Food Res. 2003, 47, 339-344.

76. Maehre, H.K.; Jensen, I.-J.; Eilertsen, K.-E. Enzymatic pre-treatment increases the protein bioaccessibility and extractability in Dulse (Palmaria palmata). Mar. Drugs 2016, 14, 196. [CrossRef] [PubMed]

77. Ganeva, V.; Galutzov, B.; Teissié, J. High yield electroextraction of proteins from yeast by a flow process. Anal. Biochem. 2003, 315, 77-84. [CrossRef]

78. Vilkhu, K.; Mawson, R.; Simons, L.; Bates, D. Applications and opportunities for ultrasound assisted extraction in the food industry-A review. Innov. Food Sci. Emerg. Technol. 2008, 9, 161-169. [CrossRef]

79. Ashokkumar, M.; Sunartio, D.; Kentish, S.; Mawson, R.; Simons, L.; Vilkhu, K.; Versteeg, C.K. Modification of food ingredients by ultrasound to improve functionality: A preliminary study on a model system. Innov. Food Sci. Emerg. Technol. 2008, 9, 155-160. [CrossRef]

80. Mason, T.; Paniwnyk, L.; Lorimer, J. The uses of ultrasound in food technology. Ultrason. Sonochem. 1996, 3 , S253-S260. [CrossRef]

81. Chemat, F.; Khan, M.K. Applications of ultrasound in food technology: Processing, preservation and extraction. Ultrason. Sonochem. 2011, 18, 813-835. [CrossRef] [PubMed]

82. Barba, F.J.; Grimi, N.; Vorobiev, E. New approaches for the use of non-conventional cell disruption technologies to extract potential food additives and nutraceuticals from microalgae. Food Eng. Rev. 2015, 7, 45-62. [CrossRef]

83. Parniakov, O.; Apicella, E.; Koubaa, M.; Barba, F.; Grimi, N.; Lebovka, N.; Pataro, G.; Ferrari, G.; Vorobiev, E. Ultrasound-assisted green solvent extraction of high-added value compounds from microalgae Nannochloropsis spp. Bioresour. Technol. 2015, 198, 262-267. [CrossRef] [PubMed]

84. Keris-Sen, U.D.; Sen, U.; Soydemir, G.; Gurol, M.D. An investigation of ultrasound effect on microalgal cell integrity and lipid extraction efficiency. Bioresour. Technol. 2014, 152, 407-413. [CrossRef] [PubMed]

85. Janczyk, P.; Wolf, C.; Souffrant, W.B. Evaluation of nutritional value and safety of the green microalgae Chlorella vulgaris treated with novel processing methods. Arch Zootech 2005, 8, 132-147.

86. Janczyk, P.; Halle, B.; Souffrant, W. Microbial community composition of the crop and ceca contents of laying hens fed diets supplemented with Chlorella vulgaris. Poult. Sci. 2009, 88, 2324-2332. [CrossRef] [PubMed]

87. Qu, W.; Ma, H.; Wang, T.; Zheng, H. Alternating two-frequency countercurrent ultrasonic-assisted extraction of protein and polysaccharide from Porphyra yezoensis. Trans. Chin. Soc. Agric. Eng. 2013, 29, 285-292.

88. Vanthoor-Koopmans, M.; Wijffels, R.H.; Barbosa, M.J.; Eppink, M.H. Biorefinery of microalgae for food and fuel. Bioresour. Technol. 2013, 135, 142-149. [CrossRef] [PubMed]

89. Fox, M.; Esveld, D.; Valero, A.; Luttge, R.; Mastwijk, H.; Bartels, P.; Van Den Berg, A.; Boom, R. Electroporation of cells in microfluidic devices: A review. Anal. Bioanal. Chem. 2006, 385, 474-485. [CrossRef] [PubMed]

90. Grahl, T.; Märkl, H. Killing of microorganisms by pulsed electric fields. Appl. Microbiol. Biotechnol. 1996, 45, 148-157. [CrossRef] [PubMed]

91. Corrales, M.; Toepfl, S.; Butz, P.; Knorr, D.; Tauscher, B. Extraction of anthocyanins from grape by-products assisted by ultrasonics, high hydrostatic pressure or pulsed electric fields: A comparison. Innov. Food Sci. Emerg. Technol. 2008, 9, 85-91. [CrossRef]

92. Joannes, C.; Sipaut, C.S.; Dayou, J.; Yasir, S.M.; Mansa, R.F. The potential of using pulsed electric field (pef) technology as the cell disruption method to extract lipid from microalgae for biodiesel production. Int. J. Renew. Energy Res. 2015, 5, 598-621.

93. Goettel, M.; Eing, C.; Gusbeth, C.; Straessner, R.; Frey, W. Pulsed electric field assisted extraction of intracellular valuables from microalgae. Algal Res. 2013, 2, 401-408. [CrossRef]

94. Zbinden, M.D.A.; Sturm, B.S.; Nord, R.D.; Carey, W.J.; Moore, D.; Shinogle, H.; Stagg-Williams, S.M. Pulsed electric field (PEF) as an intensification pretreatment for greener solvent lipid extraction from microalgae. Biotechnol. Bioeng. 2013, 110, 1605-1615. [CrossRef] [PubMed]

95. Lai, Y.S.; Parameswaran, P.; Li, A.; Baez, M.; Rittmann, B.E. Effects of pulsed electric field treatment on enhancing lipid recovery from the microalga, scenedesmus. Bioresour. Technol. 2014, 173, 457-461. [CrossRef] [PubMed] 
96. Postma, P.; Pataro, G.; Capitoli, M.; Barbosa, M.; Wijffels, R.H.; Eppink, M.; Olivieri, G.; Ferrari, G. Selective extraction of intracellular components from the microalga Chlorella vulgaris by combined pulsed electric field-temperature treatment. Bioresour. Technol. 2016, 203, 80-88. [CrossRef] [PubMed]

97. Luengo, E.; Martínez, J.M.; Coustets, M.; Álvarez, I.; Teissié, J.; Rols, M.-P.; Raso, J. A comparative study on the effects of millisecond-and microsecond-pulsed electric field treatments on the permeabilization and extraction of pigments from Chlorella vulgaris. J. Membr. Biol. 2015, 248, 883-891. [CrossRef] [PubMed]

98. Parniakov, O.; Barba, F.J.; Grimi, N.; Marchal, L.; Jubeau, S.; Lebovka, N.; Vorobiev, E. Pulsed electric field assisted extraction of nutritionally valuable compounds from microalgae Nannochloropsis spp. Using the binary mixture of organic solvents and water. Innov. Food Sci. Emerg. Technol. 2015, 27, 79-85. [CrossRef]

99. Töpfl, S. Pulsed Electric Fields (Pef) for Permeabilization of Cell Membranes in Food-and Bioprocessing-Applications, Process and Equipment Design and Cost Analysis; Berlin University of Technology: Berlin, Germany, 2006.

100. Coustets, M.; Al-Karablieh, N.; Thomsen, C.; Teissié, J. Flow process for electroextraction of total proteins from microalgae. J. Membr. Biol. 2013, 246, 751-760. [CrossRef] [PubMed]

101. Passos, F.; Carretero, J.; Ferrer, I. Comparing pretreatment methods for improving microalgae anaerobic digestion: Thermal, hydrothermal, microwave and ultrasound. Chem. Eng. J. 2015, 279, 667-672. [CrossRef]

102. Herrero, M.; Cifuentes, A.; Ibanez, E. Sub-and supercritical fluid extraction of functional ingredients from different natural sources: Plants, food-by-products, algae and microalgae: A review. Food Chem. 2006, 98, 136-148. [CrossRef]

103. Kumar, P.; Sharma, N.; Ranjan, R.; Kumar, S.; Bhat, Z.; Jeong, D.K. Perspective of membrane technology in dairy industry: A review. Asian-Australas. J. Anim. Sci. 2013, 26, 1347. [CrossRef] [PubMed]

104. Yaich, H.; Garna, H.; Besbes, S.; Paquot, M.; Blecker, C.; Attia, H. Chemical composition and functional properties of Ulva lactuca seaweed collected in Tunisia. Food Chem. 2011, 128, 895-901. [CrossRef]

105. Pafylias, I.; Cheryan, M.; Mehaia, M.; Saglam, N. Microfiltration of milk with ceramic membranes. Food Res. Int. 1996, 29, 141-146. [CrossRef]

106. Petrusevski, B.; Bolier, G.; Van Breemen, A.; Alaerts, G. Tangential flow filtration: A method to concentrate freshwater algae. Water Res. 1995, 29, 1419-1424. [CrossRef]

107. Ye, H.; Wang, K.; Zhou, C.; Liu, J.; Zeng, X. Purification, antitumor and antioxidant activities in vitro of polysaccharides from the brown seaweed Sargassum pallidum. Food Chem. 2008, 111, 428-432. [CrossRef] [PubMed]

108. Shao, P.; Chen, M.; Pei, Y.; Sun, P. In intro antioxidant activities of different sulfated polysaccharides from chlorophytan seaweeds Ulva fasciata. Int. J. Biol. Macromol. 2013, 59, 295-300. [CrossRef] [PubMed]

109. Denis, C.; Massé, A.; Fleurence, J.; Jaouen, P. Concentration and pre-purification with ultrafiltration of a r-phycoerythrin solution extracted from macro-algae grateloupia turuturu: Process definition and up-scaling. Sep. Purif. Technol. 2009, 69, 37-42. [CrossRef]

110. Safi, C.; Liu, D.Z.; Yap, B.H.; Martin, G.J.; Vaca-Garcia, C.; Pontalier, P.-Y. A two-stage ultrafiltration process for separating multiple components of Tetraselmis suecica after cell disruption. J. Appl. Phycol. 2014, 26, 2379-2387. [CrossRef]

111. American College of Sports Medicine; American Dietetic Association; Dietitians of Canada. Joint Position Statement: Nutrition and athletic performance. American College of Sports Medicine, American Dietetic Association, and Dietitians of Canada. Med. Sci. Sports Exerc. 2000, 32, 2130-2145.

112. Fleurence, J.; Morançais, M.; Dumay, J.; Decottignies, P.; Turpin, V.; Munier, M.; Garcia-Bueno, N.; Jaouen, P. What are the prospects for using seaweed in human nutrition and for marine animals raised through aquaculture? Trends Food Sci. Technol. 2012, 27, 57-61. [CrossRef]

113. Du, J. Research on functionality sports nutrition and health food security issues based on Circulation. Open Cybern. System. J. 2015, 9, 1945-1949. [CrossRef]

114. Chakdar, H.; Jadhav, S.D.; Dhar, D.W.; Pabbi, S. Potential applications of blue green algae. J. Sci. Ind. Res. 2012, 71, 13-20.

115. Tokuşoglu, Ö.; Üunal, M. Biomass nutrient profiles of three microalgae: Spirulina platensis, Chlorella vulgaris, and Isochrisis galbana. J. Food Sci. 2003, 68, 1144-1148. [CrossRef]

116. Liang, S.; Liu, X.; Chen, F.; Chen, Z. Current Microalgal Health Food R \& D Activities in China. In Asian Pacific Phycology in the 21st Century: Prospects and Challenges; Springer: Heidelberg, Germany, 2004; pp. 45-48.

117. Marcus, J.B. Enhancing umami taste in foods. In Modifying Flavour in Food; Taylor, A., Hort, J., Eds.; CRC Press: Cambridge, UK, 2007; pp. 202-220. 
118. Prabhasankar, P.; Ganesan, P.; Bhaskar, N.; Hirose, A.; Stephen, N.; Gowda, L.R.; Hosokawa, M.; Miyashita, K. Edible Japanese seaweed, wakame (Undaria pinnatifida) as an ingredient in pasta: Chemical, functional and structural evaluation. Food Chem. 2009, 115, 501-508. [CrossRef]

119. Hall, A.; Fairclough, A.; Mahadevan, K.; Paxman, J. Ascophyllum nodosum enriched bread reduces subsequent energy intake with no effect on post-prandial glucose and cholesterol in healthy, overweight males. A pilot study. Appetite 2012, 58, 379-386. [CrossRef] [PubMed]

120. Fitzgerald, C.; Gallagher, E.; Doran, L.; Auty, M.; Prieto, J.; Hayes, M. Increasing the health benefits of bread: Assessment of the physical and sensory qualities of bread formulated using a renin inhibitory Palmaria palmata protein hydrolysate. LWT-Food Sci. Technol. 2014, 56, 398-405. [CrossRef]

121. Spolaore, P.; Joannis-Cassan, C.; Duran, E.; Isambert, A. Commercial applications of microalgae. J. Biosci. Bioeng. 2006, 101, 87-96. [CrossRef] [PubMed]

122. Sajilata, M.; Singhal, R.; Kamat, M. Fractionation of lipids and purification of $\gamma$-linolenic acid (GLA) from Spirulina platensis. Food Chem. 2008, 109, 580-586. [CrossRef]

123. Khan, Z.; Bhadouria, P.; Bisen, P. Nutritional and therapeutic potential of Spirulina. Curr. Pharm. Biotechnol. 2005, 6, 373-379. [CrossRef] [PubMed]

124. Yamaguchi, K. Recent advances in microalgal bioscience in Japan, with special reference to utilization of biomass and metabolites: A review. J. Appl. Phycol. 1996, 8, 487-502. [CrossRef]

125. Yaakob, Z.; Ali, E.; Zainal, A.; Mohamad, M.; Takriff, M.S. An overview: Biomolecules from microalgae for animal feed and aquaculture. J. Biol. Res. Thessalon. 2014, 21, 1. [CrossRef] [PubMed]

126. Hayes, M. Biological Activities of Proteins and Marine-Derived Peptides from Byproducts and Seaweeds. In Marine Proteins and Peptides: Biological Activities and Applications; Kim, S.-K., Ed.; John Wiley \& Sons, Ltd.: Chichester, UK, 2013; pp. 139-165.

127. Wang, G.; Sun, H.; Fan, X.; Tseng, C. Large-scale isolation and purification of R-phycoerythrin from red alga Palmaria palmata using the expanded bed adsorption method. Acta Bot. Sin. 2001, 44, 541-546.

128. Kawakubo, A.; Makino, H.; Ohnishi, J.-I.; Hirohara, H.; Hori, K. The marine red alga Eucheuma serra J. Agardh, a high yielding source of two isolectins. J. Appl. Phycol. 1997, 9, 331-338. [CrossRef]

129. Weis, W.I.; Drickamer, K. Structural basis of lectin-carbohydrate recognition. Annu. Rev. Biochem. 1996, 65, 441-473. [CrossRef] [PubMed]

130. Ziółkowska, N.E.; Wlodawer, A. Structural studies of algal lectins with anti-HIV activity. Acta Biochim. Pol. 2006, 53, 617-626. [PubMed]

131. Naeem, A.; Saleemuddin, M.; Hasan Khan, R. Glycoprotein targeting and other applications of lectins in biotechnology. Curr. Protein Pept. Sci. 2007, 8, 261-271. [CrossRef] [PubMed]

132. Harnedy, P.A.; FitzGerald, R.J. Bioactive Proteins, Peptides, and Amino Acids from macroalgae. J. Phycol. 2011, 47, 218-232. [CrossRef] [PubMed]

133. Glazer, A.N. Phycobiliproteins-A family of valuable, widely used fluorophores. J. Appl. Phycol. 1994, 6, 105-112. [CrossRef]

134. De Marsac, N.T. Phycobiliproteins and phycobilisomes: The early observations. Photosynth. Res. 2003, 76, 193-205. [CrossRef] [PubMed]

135. Sekar, S.; Chandramohan, M. Phycobiliproteins as a commodity: Trends in applied research, patents and commercialization. J. Appl. Phycol. 2008, 20, 113-136. [CrossRef]

136. Kronick, M.; Grossman, P.D. Immunoassay techniques with fluorescent phycobiliprotein conjugates. Clin. Chem. 1983, 29, 1582-1586. [PubMed]

137. Aneiros, A.; Garateix, A. Bioactive peptides from marine sources: Pharmacological properties and isolation procedures. J. Chromatogr. B 2004, 803, 41-53. [CrossRef] [PubMed]

138. Becker, W. Microalgae in Human and Animal Nutrition. In Handbook of Microalgal Culture: Biotechnology and Applied Phycology; Richmond, A., Ed.; Wiley-Blackwell: Hoboken, NJ, USA, 2004; p. 312.

139. Holman, B.; Malau-Aduli, A. Spirulina as a livestock supplement and animal feed. J. Anim. Physiol. Anim. Nutr. 2013, 97, 615-623. [CrossRef] [PubMed]

140. Evans, F.; Critchley, A. Seaweeds for animal production use. J. Appl. Phycol. 2014, 26, 891-899. [CrossRef]

141. Allen, V.; Pond, K.; Saker, K.; Fontenot, J.; Bagley, C.; Ivy, R.; Evans, R.; Brown, C.; Miller, M.; Montgomery, J. Tasco-Forage: III. Influence of a seaweed extract on performance, monocyte immune cell response, and carcass characteristics in feedlot-finished steers. J. Anim. Sci. 2001, 79, 1032-1040. [CrossRef] [PubMed] 
142. Saker, K.; Allen, V.; Fontenot, J.; Bagley, C.; Ivy, R.; Evans, R.; Wester, D. Tasco-Forage: II. Monocyte immune cell response and performance of beef steers grazing tall fescue treated with a seaweed extract. J. Anim. Sci. 2001, 79, 1022-1031. [CrossRef] [PubMed]

143. Montgomery, J.; Allen, V.; Pond, K.; Miller, M.; Wester, D.; Brown, C.; Evans, R.; Bagley, C.; Ivy, R.; Fontenot, J. Tasco-Forage: IV. Influence of a seaweed extract applied to tall fescue pastures on sensory characteristics, shelf-life, and vitamin e status in feedlot-finished steers. J. Anim. Sci. 2001, 79, 884-894. [CrossRef] [PubMed]

144. Braden, K.; Blanton, J.; Allen, V.; Pond, K.; Miller, M. Ascophyllum nodosum supplementation: A preharvest intervention for reducing Escherichia Coli O157: H7 and Salmonella spp. In feedlot steers. J. Food Prot. 2004, 67, 1824-1828. [CrossRef]

145. Allen, V.; Pond, K.; Saker, K.; Fontenot, J.; Bagley, C.; Ivy, R.; Evans, R.; Schmidt, R.; Fike, J.; Zhang, X. Tasco: Influence of a brown seaweed on antioxidants in forages and livestock-A review. J. Anim. Sci. 2001, 79, E21-E31. [CrossRef]

146. Ginzberg, A.; Cohen, M.; Sod-Moriah, U.A.; Shany, S.; Rosenshtrauch, A.; Arad, S.M. Chickens fed with biomass of the red microalga Porphyridium sp. Have reduced blood cholesterol level and modified fatty acid composition in egg yolk. J. Appl. Phycol. 2000, 12, 325-330. [CrossRef]

147. Lorenz, R.T.; Cysewski, G.R. Commercial potential for Haematococcus microalgae as a natural source of astaxanthin. Trends Biotechnol. 2000, 18, 160-167. [CrossRef]

148. Mariey, Y.; Samak, H.; Abou-Khashba, H.; Sayed, M.; Abou-Zeid, A. Effect of using Spirulina platensis algae as a feed additives for poultry diets: 2 productive performance of broiler. Egypt. Poult. Sci. 2014, 34, 245-258.

149. Al-Batshan, H.A.; Al-Mufarrej, S.I.; Al-Homaidan, A.A.; Qureshi, M.A. Enhancement of chicken macrophage phagocytic function and nitrite production by dietary Spirulina platensis. Immunopharmacol. Immunotoxicol. 2001, 23, 281-289. [CrossRef] [PubMed]

150. Ross, E.; Dominy, W. The nutritional value of dehydrated, blue-green algae (Spirulina plantensis) for poultry. Poult. Sci. 1990, 69, 794-800. [CrossRef] [PubMed]

151. Zahroojian, N.; Moravej, H.; Shivazad, M. Effects of dietary marine algae (Spirulina platensis) on egg quality and production performance of laying hens. J. Agric. Sci. Technol. 2013, 15, 1353-1360.

152. Mariey, Y.; Samak, H.; Ibrahem, M. Effect of using Spirulina platensis algae as a feed additive for poultry diets. 1. Productive and reproductive performances of local laying hens. Egypt. Poult. Sci. 2012, 32, 201-215.

153. Anderson, D.W.; Tang, C.S.; Ross, E. The xanthophylls of Spirulina and their effect on egg-yolk pigmentationthe xanthophylls of Spirulina and their effect on egg-yolk pigmentation. Poult. Sci. 1991, 70, 115-119. [CrossRef]

154. Sujatha, T.; Narahari, D. Effect of designer diets on egg yolk composition of 'white leghorn' hens. J. Food Sci. Technol. 2011, 48, 494-497. [CrossRef] [PubMed]

155. Abudabos, A.M.; Okab, A.B.; Aljumaah, R.S.; Samara, E.M.; Abdoun, K.A.; Al-Haidary, A.A. Nutritional value of green seaweed (Ulva lactuca) for broiler chickens. Ital. J. Anim. Sci. 2013, 12, e28. [CrossRef]

156. El-Deek, A.; Brikaa, M.A. Nutritional and biological evaluation of marine seaweed as a feedstuff and as a pellet binder in poultry diet. Int. J. Poult. Sci. 2009, 8, 875-881. [CrossRef]

157. Kulshreshtha, G.; Rathgeber, B.; Stratton, G.; Thomas, N.; Evans, F.; Critchley, A.; Hafting, J.; Prithiviraj, B. Feed supplementation with red seaweeds, Chondrus crispus and Sarcodiotheca gaudichaudii, affects performance, egg quality, and gut microbiota of layer hens. Poult. Sci. 2014, 93, 2991-3001. [CrossRef] [PubMed]

158. Gatrell, S.; Lum, K.; Kim, J.; Lei, X. Nonruminant Nutrition Symposium: Potential of defatted microalgae from the biofuel industry as an ingredient to replace corn and soybean meal in swine and poultry diets. J. Anim. Sci. 2014, 92, 1306-1314. [CrossRef] [PubMed]

159. Grinstead, G.; Tokach, M.; Dritz, S.; Goodband, R.; Nelssen, J. Effects of Spirulina platensis on growth performance of weanling pigs. Anim. Feed Sci. Technol. 2000, 83, 237-247. [CrossRef]

160. Granaci, V. Achievements in the Artificial Insemination of Swine; University of Agricultural Sciences and Veterinary Medicine: Cluj-Napoca, Romania, 2007.

161. He, M.; Hollwich, W.; Rambeck, W. Supplementation of algae to the diet of pigs: A new possibility to improve the iodine content in the meat. J. Anim. Physiol. Anim. Nutr. 2002, 86, 97-104. [CrossRef]

162. Dierick, N.; Ovyn, A.; De Smet, S. Effect of feeding intact brown seaweed Ascophyllum nodosum on some digestive parameters and on iodine content in edible tissues in pigs. J. Sci. Food Agric. 2009, 89, 584-594. [CrossRef] 
163. Reilly, P.; O'doherty, J.; Pierce, K.; Callan, J.; O'sullivan, J.; Sweeney, T. The effects of seaweed extract inclusion on gut morphology, selected intestinal microbiota, nutrient digestibility, volatile fatty acid concentrations and the immune status of the weaned pig. Animal 2008, 2, 1465-1473. [CrossRef] [PubMed]

164. Angell, A.R.; Angell, S.F.; de Nys, R.; Paul, N.A. Seaweed as a protein source for mono-gastric livestock. Trends Food Sci. Technol. 2016, 54, 74-84. [CrossRef]

165. Panjaitan, T.; Quigley, S.; McLennan, S.; Poppi, D. Effect of the concentration of Spirulina (Spirulina platensis) algae in the drinking water on water intake by cattle and the proportion of algae bypassing the rumen. Anim. Prod. Sci. 2010, 50, 405-409. [CrossRef]

166. Kulpys, J.; Paulauskas, E.; Pilipavicius, V.; Stankevicius, R. Influence of cyanobacteria arthrospira (Spirulina) platensis biomass additive towards the body condition of lactation cows and biochemical milk indexes. Agron. Res 2009, 7, 823-835.

167. Christaki, E.; Karatzia, M.; Bonos, E.; Florou-Paneri, P.; Karatzias, C. Effect of dietary Spirulina Platensis on milk fatty acid profile of dairy cows. Asian J. Anim. Vet. Adv. 2012, 7, 597-604. [CrossRef]

168. Šimkus, A.; Oberauskas, V.; Laugalis, J.; Želvytè, R.; Monkevičienè, I.; Sederevičius, A.; Šimkienė, A.; Pauliukas, K. The effect of weed Spirulina platensis on the milk production in cows. Vet. Zootech. 2007, 38, 74-77.

169. Boeckaert, C.; Vlaeminck, B.; Dijkstra, J.; Issa-Zacharia, A.; Van Nespen, T.; Van Straalen, W.; Fievez, V. Effect of dietary starch or micro algae supplementation on rumen fermentation and milk fatty acid composition of dairy cows. J. Dairy Sci. 2008, 91, 4714-4727. [CrossRef] [PubMed]

170. Bezerra, L.; Silva, A.; Azevedo, S.; Mendes, R.; Mangueira, J.; Gomes, A. Performance of santa inês lambs submitted to the use of artificial milk enriched with Spirulina Platensis. Ciênc. Anim. Bras. 2010, 11, 258-263.

171. Peiretti, P.; Meineri, G. Effects of diets with increasing levels of Spirulina Platensis on the performance and apparent digestibility in growing rabbits. Livest. Sci. 2008, 118, 173-177. [CrossRef]

172. Arieli, A.; Sklan, D.; Kissil, G. A note on the nutritive value of Ulva lactuca for ruminants. Anim. Sci. 1993, 57, 329-331. [CrossRef]

173. Ventura, M.; Castañón, J. The nutritive value of seaweed (Ulva lactuca) for goats. Small Rumin. Res. 1998, 29, 325-327. [CrossRef]

174. Novoa-Garrido, M.; Aanensen, L.; Lind, V.; Larsen, H.J.S.; Jensen, S.K.; Govasmark, E.; Steinshamn, H. Immunological effects of feeding macroalgae and various vitamin e supplements in Norwegian white sheep-ewes and their offspring. Livest. Sci. 2014, 167, 126-136. [CrossRef]

175. Lio-Po, G.D.; Leaño, E.M.; Peñaranda, M.M.D.; Villa-Franco, A.U.; Sombito, C.D.; Guanzon, N.G. Anti-luminous vibrio factors associated with the 'green water'grow-out culture of the tiger shrimp Penaeus monodon. Aquaculture 2005, 250, 1-7. [CrossRef]

176. Chuntapa, B.; Powtongsook, S.; Menasveta, P. Water quality control using Spirulina Platensis in shrimp culture tanks. Aquaculture 2003, 220, 355-366. [CrossRef]

177. Borowitzka, M.A. Microalgae for aquaculture: Opportunities and constraints. J. Appl. Phycol. 1997, 9, 393-401. [CrossRef]

178. Müller-Fuega, A. Microalgae for Aquaculture: The current global situation and future trends. In Handbook of Microalgal C Ulture: Applied Phycology and Biotechnology, 2nd ed.; Richmond, A., Hu, Q., Eds.; John Wiley Sons, Ltd.: Oxford, UK, 2013; pp. 352-364.

179. Robinson, C.; Samocha, T.; Fox, J.; Gandy, R.; McKee, D. The use of inert artificial commercial food sources as replacements of traditional live food items in the culture of larval shrimp, Farfantepenaeus aztecus. Aquaculture 2005, 245, 135-147. [CrossRef]

180. Muller-Feuga, A. The role of microalgae in aquaculture: Situation and trends. J. Appl. Phycol. 2000, 12, 527-534. [CrossRef]

181. Lozano, I.; Wacyk, J.M.; Carrasco, J.; Cortez-San Martín, M.A. Red macroalgae Pyropia columbina and Gracilaria chilensis: Sustainable feed additive in the Salmo salar diet and the evaluation of potential antiviral activity against infectious salmon anemia virus. J. Appl. Phycol. 2016, 28, 1343-1351. [CrossRef]

182. Wan, A.H.; Soler-Vila, A.; O'Keeffe, D.; Casburn, P.; Fitzgerald, R.; Johnson, M.P. The inclusion of Palmaria palmata macroalgae in Atlantic salmon (Ulva lactuca) diets: Effects on growth, haematology, immunity and liver function. J. Appl. Phycol. 2016, 28, 3091-3100. [CrossRef]

183. Bansemer, M.S.; Qin, J.G.; Harris, J.O.; Howarth, G.S.; Stone, D.A. Nutritional requirements and use of macroalgae as ingredients in abalone feed. Rev. Aquac. 2016, 8, 121-135. [CrossRef] 
184. Viera, M.; de Vicose, G.C.; Gómez-Pinchetti, J.; Bilbao, A.; Fernandez-Palacios, H.; Izquierdo, M. Comparative performances of juvenile abalone (Haliotis tuberculata coccinea Reeve) fed enriched vs non-enriched macroalgae: Effect on growth and body composition. Aquaculture 2011, 319, 423-429. [CrossRef]

185. Xia, S.; Yang, H.; Li, Y.; Liu, S.; Zhou, Y.; Zhang, L. Effects of different seaweed diets on growth, digestibility, and ammonia-nitrogen production of the sea cucumber Apostichopus japonicus (selenka). Aquaculture 2012, 338, 304-308. [CrossRef]

186. Saito, T. Antihypertensive peptides derived from Bovine Casein and Whey Proteins. In Bioactive Components of Milk; Bösze, Z., Ed.; Springer: New York, NY, USA, 2008; pp. 295-317.

187. Korhonen, H.; Pihlanto, A. Bioactive peptides: Production and functionality. Int. Dairy J. 2006, 16, 945-960. [CrossRef]

188. Vercruysse, L.; Van Camp, J.; Smagghe, G. ACE inhibitory peptides derived from enzymatic hydrolysates of animal muscle protein: A review. J. Agric. Food Chem. 2005, 53, 8106-8115. [CrossRef] [PubMed]

189. Miguel, M.; Aleixandre, A. Antihypertensive peptides derived from egg proteins. J. Nutr. 2006, 136, 1457-1460. [PubMed]

190. Jung, W.K.; Mendis, E.; Je, J.Y.; Park, P.J.; Son, B.W.; Kim, H.C.; Kim, S.K. Angiotensin I-converting enzyme inhibitory peptide from yellowfin sole (Limanda aspera) frame protein and its antihypertensive effect in spontaneously hypertensive ratsangiotensin I-converting enzyme inhibitory peptide from yellowfin sole (Limanda aspera) frame protein and its antihypertensive effect in spontaneously hypertensive rats. Food Chem 2006, 94, 26.

191. Yu, Y.; Hu, J.; Miyaguchi, Y.; Bai, X.; Du, Y.; Lin, B. Isolation and characterization of angiotensin I-converting enzyme inhibitory peptides derived from porcine hemoglobin. Peptides 2006, 27, 2950-2956. [CrossRef] [PubMed]

192. Li, G.H.; Qu, M.R.; Wan, J.Z.; You, J.M. Antihypertensive effect of rice protein hydrolysate with in vitro angiotensin I-converting enzyme inhibitory activity in spontaneously hypertensive rats. Asia. Pac. J. Clin. Nutr. 2007, 16, 275-280. [PubMed]

193. Rho, S.J.; Lee, J.S.; Chung, Y.I.; Kim, Y.W.; Lee, H.G. Purification and identification of an angiotensin I-converting enzyme inhibitory peptide from fermented soybean extract. Process Biochem. 2009, 44, 490. [CrossRef]

194. Motoi, H.; Kodama, T. Isolation and characterization of angiotensin I-converting enzyme inhibitory peptides from wheat gliadin hydrolysate. Nahrung 2003, 47, 354-358. [CrossRef] [PubMed]

195. Aluko, R.E. Determination of nutritional and bioactive properties of peptides in enzymatic pea, chickpea, and mung bean protein hydrolysates. J. AOAC Int. 2008, 91, 947-956. [PubMed]

196. Lee, J.-E.; Bae, I.Y.; Lee, H.G.; Yang, C.-B. Tyr-Pro-Lys, an angiotensin I-converting enzyme inhibitory peptide derived from broccoli (Brassica oleracea Italica). Food Chem. 2006, 99, 143-148. [CrossRef]

197. Suetsuna, K. Isolation and characterization of angiotensin I-converting enzyme inhibitor dipeptides derived from Allium sativum L. (garlic) Isolation and characterization of angiotensin I-converting enzyme inhibitor dipeptides derived from. J. Nutr. Biochem. 1998, 9, 415. [CrossRef]

198. Fan, X.; Bai, L.; Zhu, L.; Yang, L.; Zhang, X. Marine algae-derived bioactive peptides for human nutrition and health. J. Agric. Food Chem. 2014, 62, 9211-9222. [CrossRef] [PubMed]

199. Beaulieu, L.; Bondu, S.; Doiron, K.; Rioux, L.-E.; Turgeon, S.L. Characterization of antibacterial activity from protein hydrolysates of the macroalga Saccharina longicruris and identification of peptides implied in bioactivity. J. Funct. Foods 2015, 17, 685-697. [CrossRef]

200. Ennamany, R.; Saboureau, D.; Mekideche, N.; Creppy, E. Secma $1^{\circledR}$, a mitogenic hexapeptide from Ulva algeae modulates the production of proteoglycans and glycosaminoglycans in human foreskin fibroblast. Hum. Exp. Toxicol. 1998, 17, 18-22. [CrossRef] [PubMed]

201. Suetsuna, K.; Nakano, T. Identification of an antihypertensive peptide from peptic digest of wakame (Undaria pinnatifida). J. Nutr. Biochem. 2000, 11, 450-454. [CrossRef]

202. Suetsuna, K.; Maekawa, K.; Chen, J.-R. Antihypertensive effects of Undaria pinnatifida (wakame) peptide on blood pressure in spontaneously hypertensive rats. J. Nutr. Biochem. 2004, 15, 267-272. [CrossRef] [PubMed]

203. Sato, M.; Hosokawa, T.; Yamaguchi, T.; Nakano, T.; Muramoto, K.; Kahara, T.; Funayama, K.; Kobayashi, A.; Nakano, T. Angiotensin I-converting enzyme inhibitory peptides derived from wakame (Undaria pinnatifida) and their antihypertensive effect in spontaneously hypertensive rats. J. Agric. Food Chem. 2002, 50, 6245-6252. [CrossRef] [PubMed] 
204. Cha, S.-H.; Ahn, G.-N.; Heo, S.-J.; Kim, K.-N.; Lee, K.-W.; Song, C.-B.; Jeon, Y.-J. Screening of extracts from marine green and brown algae in Jeju for potential marine angiotensin-I converting enzyme $(A C E)$ inhibitory activity. J. Korean Soc. Food Sci. Nutr. 2006, 35, 307-314.

205. Suetsuna, K. Purification and identification of angiotensin I-converting enzyme inhibitors from the red alga Porphyra yezoensis. J. Mar. Biotechnol. 1998, 6, 163-167. [PubMed]

206. Suetsuna, K. Separation and identification of angiotensin I-converting enzyme inhibitory peptides from peptic digest of Hizikia fusiformis protein. Nippon. Suisan. Gakkaishi. 1998, 64, 862-866. [CrossRef]

207. Furuta, T.; Miyabe, Y.; Yasui, H.; Kinoshita, Y.; Kishimura, H. Angiotensin I Converting Enzyme Inhibitory Peptides Derived from Phycobiliproteins of Dulse Palmaria palmata. Mar. Drugs 2016, 14, 32. [CrossRef] [PubMed]

208. Suetsuna, K.; Chen, J.-R. Identification of antihypertensive peptides from peptic digest of two microalgae, Chlorella vulgaris and Spirulina Platensis. Mar. Biotechnol. 2001, 3, 305-309. [CrossRef] [PubMed]

209. Qian, Z.-J.; Heo, S.-J.; Oh, C.H.; Kang, D.-H.; Jeong, S.H.; Park, W.S.; Choi, I.-W.; Jeon, Y.-J.; Jung, W.-K. Angiotensin I-Converting Enzyme (ACE) Inhibitory Peptide Isolated from Biodiesel Byproducts of Marine Microalgae, Nannochloropsis oculata. J. Biobased Mater. Bioenergy 2013, 7, 135-142. [CrossRef]

210. Samarakoon, K.W.; Kwon, O.-N.; Ko, J.-Y.; Lee, J.-H.; Kang, M.-C.; Kim, D.; Lee, J.B.; Lee, J.-S.; Jeon, Y.-J. Purification and identification of novel angiotensin-I converting enzyme $(A C E)$ inhibitory peptides from cultured marine microalgae (Nannochloropsis oculata) protein hydrolysate. J. Appl. Phycol. 2013, 25, 1595-1606. [CrossRef]

211. Ko, S.-C.; Kang, N.; Kim, E.-A.; Kang, M.C.; Lee, S.-H.; Kang, S.-M.; Lee, J.-B.; Jeon, B.-T.; Kim, S.-K.; Park, S.-J A novel angiotensin I-converting enzyme (ACE) inhibitory peptide from a marine Chlorella ellipsoidea and its antihypertensive effect in spontaneously hypertensive rats. Process Biochem. 2012, 47, 2005-2011. [CrossRef]

212. Sheih, I.-C.; Fang, T.J.; Wu, T.-K. Isolation and characterisation of a novel angiotensin I-converting enzyme (ACE) inhibitory peptide from the algae protein waste. Food Chem. 2009, 115, 279-284. [CrossRef]

213. Tierney, M.S.; Croft, A.K.; Hayes, M. A review of antihypertensive and antioxidant activities in macroalgae. Bot. Mar. 2010, 53, 387-408. [CrossRef]

214. Sheih, I.C.; Fang, T.J.; Wu, T.K.; Lin, P.H. Anticancer and antioxidant activities of the peptide fraction from algae protein waste. J. Agric. Food Chem. 2010, 58, 1202-1207. [CrossRef] [PubMed]

215. Sheih, I.C.; Wu, T.K.; Fang, T.J. Antioxidant properties of a new antioxidative peptide from algae protein waste hydrolysate in different oxidation systems. Bioresour. Technol. 2009, 100, 3419-3425. [CrossRef] [PubMed]

216. Kang, K.H.; Qian, Z.J.; Ryu, B.; Karadeniz, F.; Kim, D.; Kim, S.K. Antioxidant peptides from protein hydrolysate of microalgae Navicula incerta and their protective effects in HepG2/CYP2E1 cells induced by ethanol. Phytother. Res. 2012, 26, 1555-1563. [CrossRef] [PubMed]

217. Ko, S.-C.; Kim, D.; Jeon, Y.-J. Protective effect of a novel antioxidative peptide purified from a marine Chlorella ellipsoidea protein against free radical-induced oxidative stress. Food Chem. Toxicol. 2012, 50, 2294-2302. [CrossRef] [PubMed]

218. O'Sullivan, A.; O'Callaghan, Y.; O’Grady, M.; Queguineur, B.; Hanniffy, D.; Troy, D.; Kerry, J.; O’Brien, N. In vitro and cellular antioxidant activities of seaweed extracts prepared from five brown seaweeds harvested in spring from the west coast of Ireland. Food Chem. 2011, 126, 1064-1070. [CrossRef]

219. Heo, S.J.; Lee, G.W.; Song, C.B.; Jeon, Y.J. Antioxidant activity of enzymatic extracts from brown seaweeds. Algae 2003, 18, 71-81. [CrossRef]

220. Heo, S.-J.; Park, E.-J.; Lee, K.-W.; Jeon, Y.-J. Antioxidant activities of enzymatic extracts from brown seaweeds. Bioresour. Technol. 2005, 96, 1613-1623. [CrossRef] [PubMed]

221. Lakmal, H.C.; Samarakoon, K.W.; Lee, W.; Lee, J.-H.; Abeytunga, D.; Lee, H.-S.; Jeon, Y.-J. Anticancer and antioxidant effects of selected Sri Lankan marine algae. J. Natl. Sci. Found. Sri Lanka 2014, 42, 315-323. [CrossRef]

222. Wang, X.; Zhang, X. Separation, antitumor activities, and encapsulation of polypeptide from Chlorella pyrenoidosa. Biotechnol. Progress 2013, 29, 681-687. [CrossRef] [PubMed]

223. Zhang, B.; Zhang, X. Separation and nanoencapsulation of antitumor polypeptide from Spirulina Platensis. Biotechnol. Progress 2013, 29, 1230-1238. [CrossRef] [PubMed]

224. Cian, R.E.; Martínez-Augustin, O.; Drago, S.R. Bioactive properties of peptides obtained by enzymatic hydrolysis from protein byproducts of Porphyra columbina. Food Res. Int. 2012, 49, 364-372. [CrossRef] 
225. Shih, M.F.; Chen, L.C.; Cherng, J.Y. Chlorella 11-peptide inhibits the production of macrophage-induced adhesion molecules and reduces endothelin-1 expression and endothelial permeability. Mar. Drugs 2013, 11, 3861-3874. [CrossRef] [PubMed]

226. Vo, T.-S.; Kim, S.-K. Down-regulation of histamine-induced endothelial cell activation as potential anti-atherosclerotic activity of peptides from Spirulina maxima. Eur. J. Pharm. Sci. 2013, 50, 198-207. [CrossRef] [PubMed]

227. Vo, T.-S.; Ryu, B.; Kim, S.-K. Purification of novel anti-inflammatory peptides from enzymatic hydrolysate of the edible microalgal Spirulina maxima. J. Funct. Foods 2013, 5, 1336-1346. [CrossRef]

228. Fitzgerald, C.; Gallagher, E.; O'Connor, P.; Prieto, J.; Mora-Soler, L.; Grealy, M.; Hayes, M. Development of a seaweed derived platelet activating factor acetylhydrolase (PAF-AH) inhibitory hydrolysate, synthesis of inhibitory peptides and assessment of their toxicity using the zebrafish larvae assay. Peptides 2013, 50, 119-124. [CrossRef] [PubMed]

229. Kang, K.-H.; Qian, Z.-J.; Ryu, B.; Karadeniz, F.; Kim, D.; Kim, S.-K. Hepatic fibrosis inhibitory effect of peptides isolated from navicula incerta on TGF- $\beta 1$ Induced activation of LX-2 human hepatic stellate cells. Prev. Nutr. Food Sci. 2013, 18, 124-132. [CrossRef] [PubMed]

230. Ahn, G.; Hwang, I.; Park, E.; Kim, J.; Jeon, Y.-J.; Lee, J.; Park, J.W.; Jee, Y. Immunomodulatory effects of an enzymatic extract from Ecklonia cava on murine splenocytes. Mar. Biotechnol. 2008, 10, 278-289. [CrossRef] [PubMed]

231. Chen, C.-L.; Liou, S.-F.; Chen, S.-J.; Shih, M.-F. Protective effects of Chlorella-derived peptide on uvb-induced production of MMP-1 and degradation of procollagen genes in human skin fibroblasts. Regul. Toxicol. Pharm. 2011, 60, 112-119. [CrossRef] [PubMed]

232. Shih, M.-F.; Cherng, J.-Y. Potential protective effect of fresh grown unicellular green algae component (resilient factor) against PMA-and UVB-induced MMP1 expression in skin fibroblasts. Eur. J. Dermatol. 2008, 18, 303-307. [PubMed]

233. Nguyen, M.H.T.; Qian, Z.-J.; Nguyen, V.-T.; Choi, I.-W.; Heo, S.-J.; Oh, C.H.; Kang, D.-H.; Kim, G.H.; Jung, W.-K. Tetrameric peptide purified from hydrolysates of biodiesel byproducts of Nannochloropsis oculata induces osteoblastic differentiation through MAPK and SMAD pathway on MG-63 and D1 cells. Process Biochem. 2013, 48, 1387-1394. [CrossRef]

234. Athukorala, Y.; Lee, K.-W.; Kim, S.-K.; Jeon, Y.-J. Anticoagulant activity of marine green and brown algae collected from Jeju Island in Korea. Bioresour. Technol. 2007, 98, 1711-1716. [CrossRef] [PubMed]

235. Cian, R.E.; Garzón, A.G.; Ancona, D.B.; Guerrero, L.C.; Drago, S.R. Hydrolyzates from Pyropia columbina seaweed have antiplatelet aggregation, antioxidant and ACE I inhibitory peptides which maintain bioactivity after simulated gastrointestinal digestion. LWT-Food Sci. Technol. 2015, 64, 881-888. [CrossRef]

236. Vermeirssen, V.; Van Camp, J.; Verstraete, W. Bioavailability of angiotensin I converting enzyme inhibitory peptides. Br. J. Nutr. 2004, 92, 357-366. [CrossRef] [PubMed]

237. World Heath Organization. Global Health Risks: Mortality and Burden of Disease Attributable to Selected Major Risks; World Health Organization: Geneva, Switzerland, 2009.

238. Turk, B. Targeting proteases: Successes, failures and future prospects. Nature Rev. Drug Discov. 2006, 5, 785-799. [CrossRef] [PubMed]

239. Chen, Z.-Y.; Peng, C.; Jiao, R.; Wong, Y.M.; Yang, N.; Huang, Y. Anti-hypertensive nutraceuticals and functional foods. J. Agric. Food Chem. 2009, 57, 4485-4499. [CrossRef] [PubMed]

240. Wu, Q.; Cai, Q.-F.; Yoshida, A.; Sun, L.-C.; Liu, Y.-X.; Liu, G.-M.; Su, W.-J.; Cao, M.-J. Purification and characterization of two novel angiotensin I-converting enzyme inhibitory peptides derived from r-phycoerythrin of red algae (Bangia fusco-purpurea). Eur. Food Res. Technol. 2017, 243, 779-789. [CrossRef]

241. Fitzgerald, C.N.; Mora-Soler, L.; Gallagher, E.; O'Connor, P.; Prieto, J.; Soler-Vila, A.; Hayes, M. Isolation and characterization of bioactive pro-peptides with in vitro renin inhibitory activities from the macroalga Palmaria palmata. J. Agric. Food Chem. 2012, 60, 7421-7427. [CrossRef] [PubMed]

242. Verdecchia, P.; Angeli, F.; Mazzotta, G.; Gentile, G.; Reboldi, G. The renin angiotensin system in the development of cardiovascular disease: Role of aliskiren in risk reduction. Vasc. Health Risk Manag. 2008, 4, 971-981. [CrossRef] [PubMed]

243. Werner, A.; Kraan, S. Review of the Potential Mechanisation of Kelp Harvesting in Ireland; Marine Institute: Dublin, Ireland, 2004; p. 52. 
244. Werner, A.; Clarke, D.; Kraan, S. Strategic Review and the Feasibility of Seaweed Aquaculture in Ireland; Irish Seaweed Centre, Martin Ryan Institute, National University of Ireland: Galway, Ireland, 2004; p. 120.

245. De Grave, S.; Fazakerley, H.; Kelly, L.; Guiry, M.; Ryan, M.; Walshe, J. A Study of Selected MaëRl Beds in Irish Waters and Their Potential for Sustainable Extraction; Marine Institute: Dublin, Ireland, 2000.

246. Stengel, D.B.; Connan, S.; Popper, Z.A. Algal chemodiversity and bioactivity: Sources of natural variability and implications for commercial application. Biotechnol. Adv. 2011, 29, 483-501. [CrossRef] [PubMed]

247. Galland-Irmouli, A.-V.; Fleurence, J.; Lamghari, R.; Luçon, M.; Rouxel, C.; Barbaroux, O.; Bronowicki, J.-P.; Villaume, C.; Guéant, J.-L. Nutritional value of proteins from edible seaweed Palmaria palmata (dulse). J. Nutr. Biochem. 1999, 10, 353-359. [CrossRef]

248. Marinho-Soriano, E.; Fonseca, P.; Carneiro, M.; Moreira, W. Seasonal variation in the chemical composition of two tropical seaweeds. Bioresour. Technol. 2006, 97, 2402-2406. [CrossRef] [PubMed]

249. Zhou, A.Y.; Robertson, J.; Hamid, N.; Ma, Q.; Lu, J. Changes in total nitrogen and amino acid composition of New Zealand Undaria pinnatifida with growth, location and plant parts. Food Chem. 2015, 186, 319-325. [CrossRef] [PubMed]

250. Sheng, J.; Vannela, R.; Rittmann, B. Disruption of Synechocystis PCC 6803 for lipid extraction. Water Sci. Technol. 2012, 65, 567-573. [CrossRef] [PubMed]

251. Marrion, O.; Fleurence, J.; Schwertz, A.; Guéant, J.-L.; Mamelouk, L.; Ksouri, J.; Villaume, C. Evaluation of protein in vitro digestibility of Palmaria palmata and Gracilaria verrucosa. J. Appl. Phycol. 2005, 17, 99-102. [CrossRef]

252. Meade, S.J.; Reid, E.A.; Gerrard, J.A. The impact of processing on the nutritional quality of food proteins. J. AOAC Int. 2005, 88, 904-922. [PubMed]

253. Maehre, H.K.; Edvinsen, G.K.; Eilertsen, K.-E.; Elvevoll, E.O. Heat treatment increases the protein bioaccessibility in the red seaweed dulse (Palmaria palmata), but not in the brown seaweed winged kelp (Alaria esculenta). J. Appl. Phycol. 2016, 28, 581-590. [CrossRef]

254. Setting Maximum Levels for Certain Contaminants in Foodstuffs. 2006. Available online: https:/ /www.fsai. ie/uploadedFiles/Consol_Reg1881_2006.pdf (accessed on 20 April 2017).

255. Opinion of the Scientific Panel on Contaminants in the Food Chain on a request from the Commission Related to Mercury and Methylmercury in Food. Available online: http://www.efsa.europa.eu/sites/ default/files/scientific_output/files/main_documents/34.pdf (accessed on 20 April 2017).

256. European Food Safety Authority. Scientific Opinion on Arsenic in Food. EFSA Panel on Contaminants in the Food Chain. Available online: http://www.iss.it/binary/meta/cont/AsSummary2009en.pdf (accessed on 20 April 2017).

257. European Food Safety Authority. Scientific Opinion on Lead in Food. EFSA Panel on Contaminants in the Food Chain. Available online: http://www.iss.it/binary/meta/cont/Pb_Opinion2010.pdf (accessed on 20 April 2017).

258. European Food Safety Authority. Statement on Tolerable Weekly Intake for Cadmium. EFSA Panel on Contaminants in the Food Chain. Available online: http:/ /www.megapesca.com/megashop/FH201102_ tgf/EFSA_Scientific_Opinion_Cadmium.pdf (accessed on 20 April 2017).

259. Almela, C.; Algora, S.; Benito, V.; Clemente, M.; Devesa, V.; Suner, M.; Velez, D.; Montoro, R. Heavy metal, total arsenic, and inorganic arsenic contents of algae food products. J. Agric. Food Chem. 2002, 50, 918-923. [CrossRef] [PubMed]

260. Besada, V.; Andrade, J.M.; Schultze, F.; González, J.J. Heavy metals in edible seaweeds commercialised for human consumption. J. Mar. Syst. 2009, 75, 305-313. [CrossRef]

261. Van der Spiegel, M.; Noordam, M.; Fels-Klerx, H. Safety of novel protein sources (insects, microalgae, seaweed, duckweed, and rapeseed) and legislative aspects for their application in food and feed production. Compr. Rev. Food Sci. Food Saf. 2013, 12, 662-678. [CrossRef]

262. Grobbelaar, J.U. Quality control and assurance: Crucial for the sustainability of the applied phycology industry. J. Appl. Phycol. 2003, 15, 209-215. [CrossRef]

263. Görs, M.; Schumann, R.; Hepperle, D.; Karsten, U. Quality analysis of commercial Chlorella products used as dietary supplement in human nutrition. J. Appl. Phycol. 2010, 22, 265-276. [CrossRef]

264. Harnedy, P.A.; FitzGerald, R.J. Extraction and Enrichment of Protein from red and green Macroalgae. Nat. Prod. Mar. Algae Methods Protoc. 2015, 1308, 103-108. 
265. Machmudah, S.; Shotipruk, A.; Goto, M.; Sasaki, M.; Hirose, T. Extraction of Astaxanthin from Haematococcus pluvialis Using Supercritical $\mathrm{CO}_{2}$ and Ethanol as Entrainer. Ind. Eng. Chem. Res. 2006, 45, 3652-3657. [CrossRef]

266. Cuellar-Bermudez, S.P.; Aguilar-Hernandez, I.; Cardenas-Chavez, D.L.; Ornelas-Soto, N.; Romero-Ogawa, M.A.; Parra-Saldivar, R. Extraction and purification of high-value metabolites from microalgae: Essential lipids, astaxanthin and phycobiliproteins. Microb. Biotechnol. 2015, 8, 190-209. [CrossRef] [PubMed]

267. Marella, C.; Muthukumarappan, K.; Metzger, L. Application of membrane separation technology for developing novel dairy food ingredients. J. Food Process. Technol. 2013, 4. [CrossRef]

268. Van Hal, J.W.; Huijgen, W.; López-Contreras, A. Opportunities and challenges for seaweed in the biobased economy. Trends Biotechnol. 2014, 32, 231-233. [CrossRef] [PubMed]

(C) 2017 by the authors. Licensee MDPI, Basel, Switzerland. This article is an open access article distributed under the terms and conditions of the Creative Commons Attribution (CC BY) license (http:/ / creativecommons.org/licenses/by/4.0/). 